\title{
Bank switching of US small businesses: new methods and evidence
}

\author{
Song Zhang ${ }^{1}$ (D) $\cdot$ Liang Han $^{2} \cdot$ Konstantinos Kallias $^{3} \cdot$ Antonios Kallias $^{4}$
}

Accepted: 30 November 2021 / Published online: 4 January 2022

(c) The Author(s) 2022

\begin{abstract}
Despite being informationally opaque, small firms often switch from their primary financial institution to transactional lenders, with the relationship banking theory invoking the holdup problem as a culprit explanation. Using US evidence and an estimation strategy that overcomes traditional shortcomings in small business research, our study captures the determinants and, for the first time, the ex post effects of the switching decision. We find that switching is less likely when the primary financial institution is a nearby bank associated with quality services and connected to the firm via other business or social relationships. Small firms become more loyal as they grow in size and pursue nonmortgage credit. Outside the primary relationship, both loan approval and borrowing cost are adversely impacted, however loan maturities are longer. Moreover, the likelihood of pledging collateral remains unaffected, provided that the type of collateral is least sensitive to the borrower's information environment. Jointly, our findings describe a trade-off inconsistent with the holdup problem, and an opportunity for banks to enhance customer loyalty by improving aspects of the relationship unrelated to the terms of credit.
\end{abstract}

Keywords Small business $\cdot$ Relationship banking $\cdot$ IPTW propensity score $\cdot$ Entropy balancing

JEL Classification G20 · G29 • G30 · L26

Song Zhang

sz59@st-andrews.ac.uk

Liang Han

liang.han@ henley.ac.uk

Konstantinos Kallias

konstantinos.kallias@port.ac.uk

Antonios Kallias

kalliasa@cardiff.ac.uk

1 Centre for Responsible Banking and Finance, School of Management, University of St Andrews, St Andrews KY16 9RJ, UK

2 Henley Business School, University of Reading, Reading RG6 6UD, UK

3 Portsmouth Business School, University of Portsmouth, Portsmouth PO1 3DE, UK

4 Cardiff Business School, Cardiff University, Colum Drive, Cardiff CF10 3EU, UK 


\section{Introduction}

Asymmetric information plays an important role in determining the financing choices of small businesses (Ang 1991; Crawford et al. 2018). Relationship lending is suggested as an effective way of leveling the informational playing field because of lenders' ability to operationalize soft information garnered from the entire spectrum of interactions with small business customers (Boot 2000; Levine et al. 2019; Liberti and Petersen 2019). However, as the relationship evolves, a holdup problem is likely to arise if banks use their information advantage to extract further rents from borrowers (Sharpe 1990). Consequently, there is a trade-off between the favorable and detrimental effects of relationship lending, and a mixed bag of findings in the literature as to how the surplus value created is apportioned between borrowers and lenders. For example, Hernandez-Canovas and Martines-Solano (2010) and Bharath et al. (2011) use the decrease in loan spreads and improved availability of finance, respectively, to report a favorable net effect. Others are more ambivalent, suggesting that the competing forces serve to offset each other, so that relationship lending and loan prices are ultimately unrelated (e.g., Petersen and Rajan 1994; Wu and Chua 2012). When the holdup problem dominates, loan rates become an increasing function of the relationship length, suggesting a detrimental net effect (Degryse and Ongena 2005). However, the holdup problem can be eliminated if the firm responds by turning to another provider of finance (Degryse and Cayseele 2000; Farinha and Santos 2002; Ioannidou and Ongena 2010; Gopalan et al. 2011).

The phenomenon of borrowing from a nonprimary financial institution (bank switching hereafter) remains to date largely unexplored in the context of small business. Paradoxically, it is within this context that information asymmetry becomes highest, increasing both the motivation for switching, as the incumbent bank is left with ample scope for rent extraction over informationally captive borrowers, and the cost of switching, as thirdparty financiers confronted with the adverse selection problem tend to indiscriminately peg these borrowers as "lemons." Consequently, the choice of lender for small businesses is a fragile balancing act. Given that relationship (transactional) lending is conducted with the primary (nonprimary) financial institution (Ono et al. 2014), a portion of firms ultimately acquiesce to the higher level of information asymmetry that characterizes arm'slength financing, indicating a growing level of discontent within the incumbent banking relationship. According to the Federal Reserve's Survey of Small Business Finances (SSBF 2003), the most recent (within one year from the survey) loan application submitted by $34 \%$ of US small businesses targets a nonprimary financial institution. The observed heterogeneity raises two important questions. When is a small firm more likely to seek credit outside its primary bank? Does switching to an alternate lender lead to a better financing arrangement?

With the small business literature partially addressing the former question and completely ignoring the latter, the present study is aimed at offering a symmetrical understanding of both the determinants and implications of the switching behavior. The motivation to extend and complement this strand of research emanates from the importance of bank credit as the prime and often sole source of external finance for small businesses (Mkhaiber and Werner 2021) as well as from the central role these firms play in the economy, accounting for about half of the private-sector employment and overall US economic activity. ${ }^{1}$ Focal

\footnotetext{
${ }^{1}$ The data are sourced from the Office of Advocacy of the US Small Business Administration.
} 
to our investigation is a hitherto ignored SSBF question, requesting the surveyed firms to identify whether the most recent loan application was submitted to their primary financial institution or another potential lender. We study the available responses corresponding to 1326 unique firms and use appropriate weighting to make these representative of the population of US small businesses. Exploiting a host of other survey questions, we delineate the characteristics making certain firms more liable than others to switch at the levels of firm and owner, loan contract, banking relationship, and market structure. Subsequently, we assess the impact of switching across an array of outcomes: loan approval; interest rate; maturity; the probability of using guaranty or collateral; and collateral type.

Our analysis yields a rich crop of empirical findings. On the determinants' side, we first observe that the probability of switching decreases with firm size. The economic significance of this result is large, highlighting the salience of bank switching in the small business context. Specifically, the likelihood of borrowing from a nonprimary source of finance decreases by $0.93 \%$ for every additional employee. Furthermore, aligned with the comparative advantage of banks in lending to informationally opaque enterprises, switching is less probable when the primary financial institution is a bank. With these exceptions, we document the irrelevance of most other theoretically identified variables relating to owner, firm and banking market characteristics. We convey instead the novel insight that features peripheral to the terms of credit are likely to exert a formative influence on consolidating a relationship. One of them is the convenience factor implicit in the positive association between the physical distance separating the firm from its primary financial institution and the former's propensity to divert a new loan application away from the latter. Other factors positively affecting small businesses' loyalty include service quality and the occurrence of special business or interpersonal connections. Overall, the borrower's choice is proven more contextual and sensitive to individual preferences, and less conforming to the predictions of traditional relationship banking theory.

Turning to the ex post effects of switching, we caution that this is both an uncertain and a costly endeavor. A loan application submitted to a new financier is less likely to be approved; if successful, the associated loan will be issued with an interest rate that is higher than the rate quoted by the primary institution. Evidently the incumbent bank refrains from using its informational advantage for rent extraction, which offers empirical grounding to the synergistic view of relationship banking as per Diamond (1989) and Boot and Thakor (1994). Yet a plausible incentive for switching could comprise the prolonged loan maturities offered by transactional lenders. The difference is economically significant, with the typical loan coming due about two months later. Finally, although the likelihood of using guaranty or pledging collateral remains unaffected when borrowing from a nonprimary financial institution, we observe a smaller probability of collateral types that require a high degree of borrower-specific information, such as accounts receivable or owners' personal (non-real-estate) assets.

The implications for banks focused on enhancing customer loyalty and for small businesses pondering the what-ifs of switching are unambiguous, while suggesting that the latter organizations may dispel suspicion about the former. When a small firm's investment horizon is better served by a longer maturity, borrowing outside of the relationship might be advantageous, but informed decision-making also requires awareness of the existence of a premium in the form of higher interest rates. For banks, an alternate route to customer retention emerges that is independent of the individual loan deal. This suggests a shift of focus from the terms of credit to the overall experience from the relationship, and it highlights the importance of investing in the soft elements of the relationship through networking and the development of multifaceted ties with customers. 
Grounded in the relationship lending and banking market structure theories of Petersen and Rajan (1994 and 1995), this paper falls into the broader area of bank switching. Notable exceptions to the scant empirical evidence include the studies of Ongena and Smith (2001), Farinha and Santos (2002), Berger et al. (2005), Ioannidou and Ongena (2010), Degryse et al. (2011), Barone, G. et al. (2011), Gopalan et al. (2011) and Bonfim et al. (2021). Our contribution is incremental to these studies in the following ways. First, in contrast to the bank-side research (e.g., Berger et al. 2005), we examine the relationship from the perspective of small business and elucidate previously unknown facets of it. Second, unlike a passive switch imposed by consolidation in the banking market (Degryse et al. 2011), our study endogenizes bank switching, allowing for the voluntary selection of lenders by borrowers who actively shop around for better financing terms. Our scope is also more comprehensive in that we consider relationships developed with any type of financial institution rather than with banks only. Third, we maintain an exclusive focus on small businesses, i.e., the type of firms for which bank credit matters the most. This approach stands in contrast to the samples used in Ongena and Smith (2001), Farinha and Santos (2002), Ioannidou and Ongena (2010), Barone et al. (2011), Gopalan (2011) and Bonfim et al. (2021), which include larger firms that have a menu of financing options inaccessible to their smaller counterparts. Fourth, the choice of the US for our empirical setting enables us to investigate and control for the effect of local banking market concentration, a catalyst for the appropriation of credit in small business finance (Petersen and Rajan 1995; Han et al. 2017). Fifth, in contrast to prior studies that find a negative relationship between borrowing cost and switching (e.g., Ioannidou and Ongena, 2010; Barone et al. 2011; Bonfim et al. 2021), we document a higher borrowing cost associated with the bank switching for small businesses in the US and we conduct further analysis to propose an alternative mechanism to explain the phenomenon. On the methodological front, we are also the first in the research of small business to address potential endogeneity through the use of inverse-probability treatment weighting (IPTW) and entropy balancing. Unlike the common two-stage instrumental variables approach, these methods obviate the need for exogenous regressors to satisfy the exclusion restriction, which is important considering the scarcity of environmental information in small business surveys (including basic identification such as the address of headquarters). Also, compared to simple propensity score matching, both methods have the added benefits of using the entirety of observations and generating an estimate for each covariate, not just for the treatment variable, which is key to illuminating the determinants of previously unexplored outcomes such as the type of collateral posted.

The remainder of the paper is structured as follows. Section 2 positions this study within the relevant literature. Section 3 provides an overview of the data set and the main variables. The regression results are in Sect. 4. Finally, Sect. 5 concludes the paper.

\section{Literature review}

With a limited footprint in the business community and few resources to commit to the development of effective accounting records, small businesses breed acute information asymmetries (Ou and Haynes 2006). An uneven informational playing field, in turn, accentuates a prospective financier's concerns over (1) adverse selection, i.e., it is precarious to determine the quality of the firm's project pipeline; and (2) moral hazard, i.e., it is possible that the business owner elects to pursue riskier projects with asymmetric payoffs to each 
capital provider in different states of the world. Jointly, these concerns create a deadweight loss, which small businesses and their lenders incur in the form of higher cost of finance and higher information acquisition cost, respectively (Darrough and Stoughton 1986; Ang 1991). There are two ways of ameliorating this lose-lose situation. First, the liability of newness naturally subsides over time, with plenty of empirical evidence supporting the intuition that as small firms become more established and obtain a substantive track record, bank loans become cheaper and available for longer periods (Serrasqueiro and Nunes 2012; Peltoniemi and Vieru 2013; Deng et al. 2014). The alternate route of mitigating the problem of asymmetric information and unblocking access to finance is relationship lending (Berger and Udell 1995). The comparative advantage of this lending technology pertains to the ability to inform the lending decision with hard as well as soft information, which serves to overcome information opacity due to inadequate accounting records. The dark side of relationship lending is the "holdup" problem, the situation arising when lenders exploit their superior information about the small business to increase the rate on the associated loans (Degryse and Cayseele 2000). Although the equilibrium point between the negative effects of the holdup problem and the favorable effects of relationship banking is subject to conflicting empirical and theoretical predictions, small firms are known to react to an unfavorable balance by seeking financing from sources external to the relationship (Gopalan et al. 2011). We devote the rest of this section to an overview of the seminal studies and the current state of the art in the research on bank switching.

\subsection{Theoretical models}

In seminal studies, Diamond (1989) and Boot and Thakor (1994) developed theoretical models to describe the value added of relationship banking. Diamond (1989) indicates that, due to adverse selection and moral hazard concerns, borrowers with a limited track record are invariably offered high interest rates at the inception of a relationship. The fraction of borrowers who will remain in the relationship for an adequately long period of time without incidences of default or delinquent behavior are liable to earn a reputation with the bank, rewarded by a gradual reduction in rates. This dynamic element in the pricing of credit - a testament to the bank's ability to fulfill its role as a repository of informationexerts a formative influence on borrowers' investment choices by incentivizing the selection of low-risk projects that usually preserve reputation capital. Boot and Thakor (1994) document a similar reduction in loan rates over the course of the relationship, even in models lacking a learning component. Furthermore, they find that the probability of pledging collateral also diminishes with time. Thus, both studies arrive at the conclusion that relationship lending, unlike transactional lending, creates a surplus value that banks share with borrowers of good quality - the economic rationale for the latter to stay in the relationship.

The holdup problem and the ensuing motivation for bank switching enter the theoretical predictions of Sharpe (1990), Rajan (1992), and Von Thadden (2004). These models are based on similar underpinning assumptions about the capacity of relationship lending to alleviate the problem of asymmetric information, as well as the ability of banks to maintain an information advantage developed from the entirety of their interactions with borrowers. Sharpe (1990) models the cost of a borrower's switching attributable to adverse selection. Over the course of the relationship, the incumbent bank is shown to acquire insight about borrower-specific characteristics, which a small firm is unable to credibly reveal to the rest of the market. It is noteworthy that an informationally captured borrower still receives the best offer in the market; however, this is only because competing banks are unable to see 
through the information opacity. If firms switch, they are inevitably pooled together with low-quality borrowers and charged a higher interest rate. Rajan (1992) argues that it is exactly due to this informational advantage that insider banks are successful at extracting rents from borrowers. In essence, while relational banks prevent borrowers' positive NPV projects from going awry, they effectively impose a profit-sharing scheme, which distorts firms' investment incentives. Ioannidou and Ongena (2010) describe this behavior as typical of monopoly-like power. Rajan (1992) concurs that borrowing from alternative sources of finance and setting priorities in debt claims may counter the relational bank's monopoly, tempering both the costs and the benefits of relationship lending. In Von Thadden's (2004) revision of Sharpe's (1990) model, borrowers could even attain lower rates outside the relationship, with the riskier of them appearing more probable to switch. As an extension to the above traditional models developed by Sharpe (1990), Rajan (1992) and von Thadden (2004), a recent study by Niinimäki (2021) confirms the existence of the holdup problem, while highlighting the need for further empirical work to shed light on the precise sources of the switching costs.

\subsection{Empirical literature}

Ample empirical research has examined the impact of relationship banking on the availability and cost of finance. A lower borrowing cost has been documented by Berger and Udell (1995), Athavale and Edmister (2004), Brick and Palia (2007), and Bharath et al. (2011). The improved availability of finance emerges as a common theme in the studies by Petersen and Rajan (1994), Berger and Udell (1995), Angelini et al. (1998), Chakraborty and Hu (2006), Jimenez et al. (2006), Hernandez-Canovas and Martines-Solano (2010), and Bharath et al. (2011). Relationship banking is also known to fulfill an important monitoring role. Dass and Massa (2011) view substantial incentives (e.g., maintaining leverage at a target level or preserving the collateral value) for a bank to pressure borrowers against the wasteful use of available resources, and demonstrate how this pressure has a sobering effect commensurate with the intensity of the relationship.

However, there are also numerous studies to predict that such positive effects are bound to dissipate over time due to the intrusion of the holdup problem. Typified by Angelini et al. (1998), D'Auria et al. (1999), Degryse and Cayseele (2000), and Hanley and Crook (2005), this research evidences a gradual rise of interest rates to levels that are high enough to counter the motivation that drew the firm into relationship banking initially. ${ }^{2}$ Largersized businesses have been shown to respond to holdup by switching banks, with the twofold aim of maximizing loan proceeds (Gopalan et al. 2011) and containing the interest expense (Ioannidou and Ongena 2010). We are however left with no indication of how small businesses behave when confronted with a similar problem.

\subsection{Related literature}

To date, there have been only a handful of studies maintaining an explicit or incidental focus on bank switching (Ongena and Smith 2001; Farinha and Santos 2002; Berger et al. 2005; Ioannidou and Ongena 2010; Degryse et al. 2011; Gopalan et al. 2011; Barone et al. 2011; Ogane 2019; Bonfim et al. 2021). Table 1 summarizes the key differences between

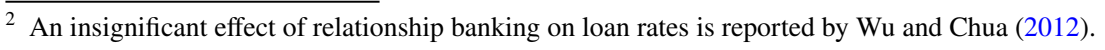




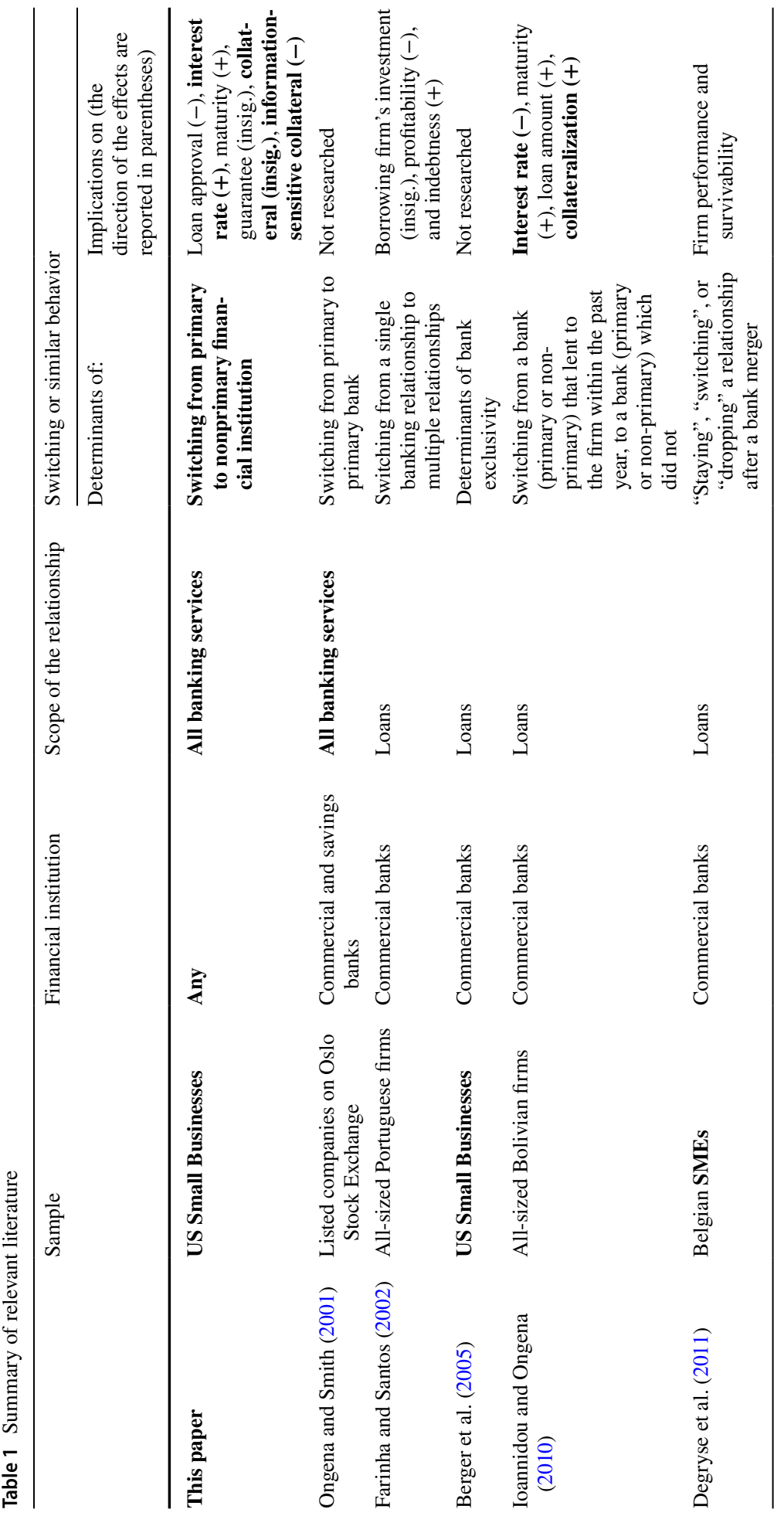




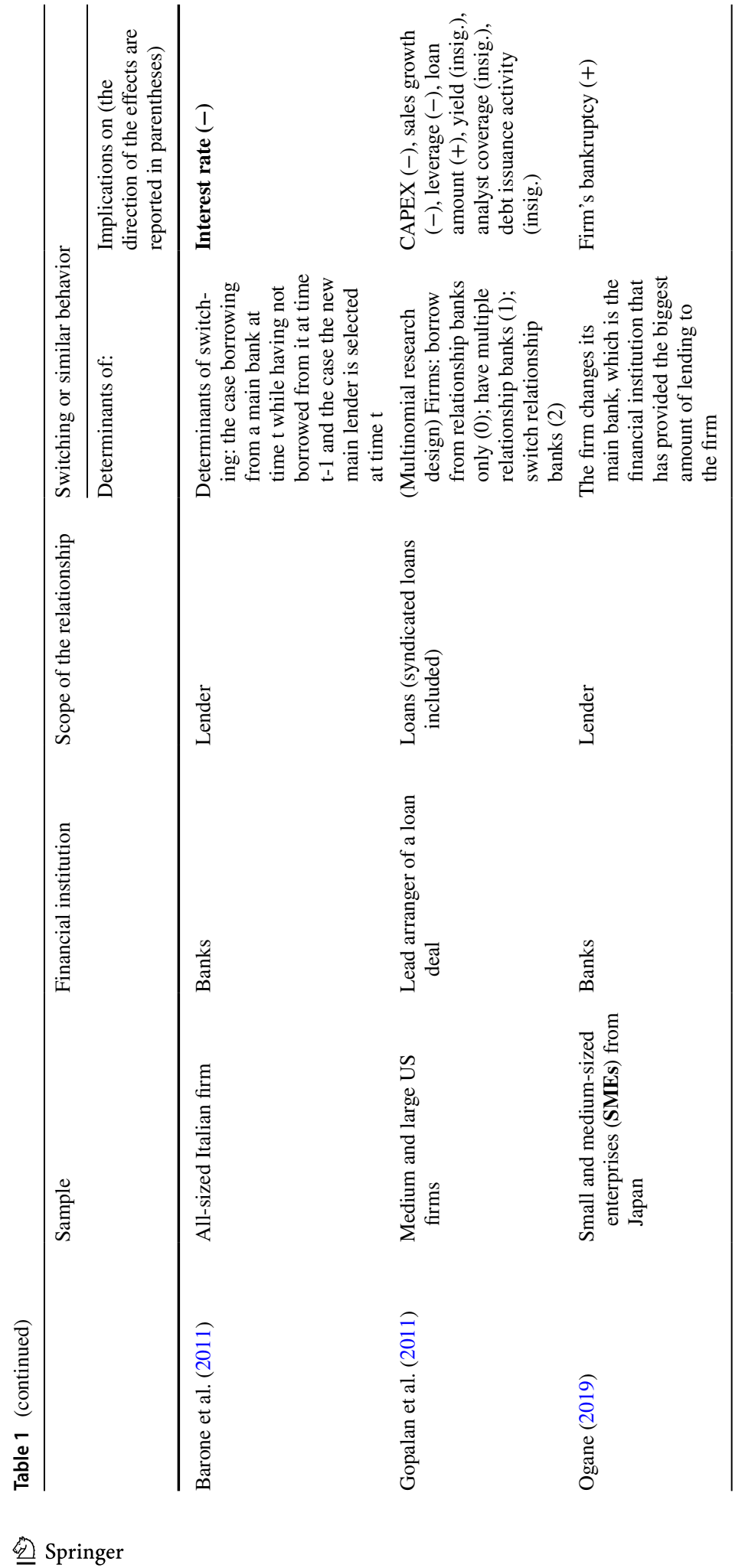




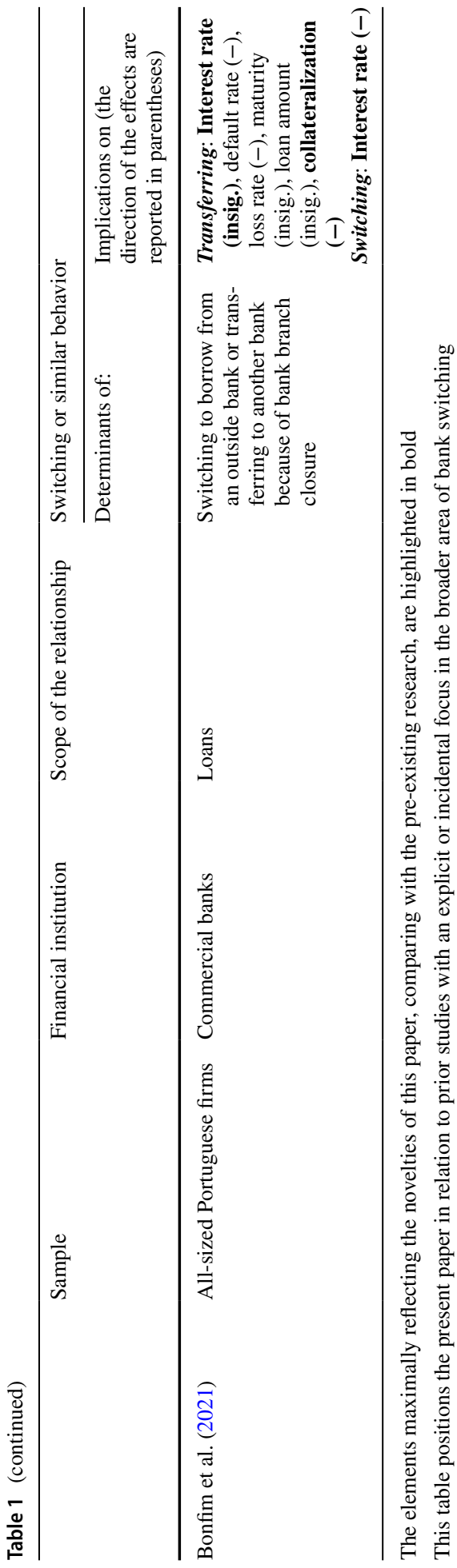


these studies and the present paper. An immediate point of differentiation is that all of them, except Berger et al. (2005), draw evidence from samples that either make no distinction on firm size or entirely exclude small firms. However, the salience of the credit provider remains fundamentally different for firms relying on bank loans as their main source of external capital and firms that have a menu of financing options, including the option to tap the public debt or equity markets.

Conflicting insights about the determinants of bank switching come indirectly through the analysis of the duration of bank relationships, and the extent to which these are exclusive. Using a sample of firms listed on the Oslo Stock Exchange, Ongena and Smith (2001) document that profitable and highly leveraged firms are more likely to terminate a banking relationship, whereas Farinha and Santos (2002), with all-sized firm data from Portugal, find relationships tend to end earlier when firms struggle with profitability. En route to investigating the comparative advantage of small banks in small business lending, Berger et al. (2005) regress a number of firm and bank characteristics on the likelihood of forming exclusive banking relationships, and establish an inverse correlation with firm size, the sole firm characteristic attaining statistical significance in their tests. Nonexclusivity, however, need not equate to bank switching. In our sample, the majority of firms that borrow from multiple lenders-Berger et al.'s definition of nonexclusivity - continue to submit their most recent loan application to the primary bank.

Degryse et al. (2011) and Gopalan et al. (2011) assess firms' financial standing and future prospects in the aftermath of a voluntary bank switch and an exogenously imposed switch due to banking market consolidation, respectively. Both studies describe a positive net effect. Ioannidou and Ongena (2010) use a comprehensive data set of Bolivian bank loans to add a caveat: although the new bank tends to lure with the provision of cheaper credit, the holdup problem emerges strongly again, renewing the motivation for subsequent switches. In the research design of Ioannidou and Ongena (2010), the switching decision concerns the transition from an inside bank, the bank that lent to the firm at least once within the past year, and an outside bank that did not. As a way of identifying relational banks, this distinction suffers from a double shortcoming, as it precludes (1) firms without a borrowing need within the said period and (2) a multitude of nonlending interactions that generate key inside information. Such information forms an integral part of the lending decision for a bank that normally provides a business customer with a host of other services (e.g., checking/savings account, cash management, brokerage, insurance, factoring, and foreign exchange management). Similarly, the studies by Barone et al. (2011) and Bonfim et al. (2021) also arrive at the common conclusion of a lower interest rate following bank switching. From a complementary angle, Ogane (2019), through the analysis of a large sample of young SMEs from Japan, cautions that switching the main bank increases the likelihood of firm bankruptcy, with the effect being driven by the firms that had switched to a bank with whom they had no prior transactions.

By introducing the primary bank as a focal point for distinguishing relational from transactional lenders, the present study attends to the nature of relationship banking in a holistic manner. Note that we are not the first to use the primary bank in the study of bank switching. Ongena and Smith (2001) maintain an exclusive focus on primary banks. In particular, they allow for multiple (up to four) primary banks and examine how borrowers switch among them. This is conducive to understanding how borrowers switch from one bank to another. Unlike Ongena and Smith, we take into account the entire spectrum of a firm's banking relationships and identify the primary bank as the single most frequently used financial institution, i.e., the largest repository of borrower-specific information. Additionally, our scope is comprehensive enough to include banks as well as nonbank 
financial institutions. Thus, our lens of bank switching is focused on examining borrowers that endogenously choose to migrate from a status of low information asymmetry, inherent in the relationship with the primary financial institution, to a status of higher information asymmetry, inherent in borrowing from nonprimary sources.

\section{Data, variables, and univariate analysis}

\subsection{Data}

All data come from the US Federal Reserve's 2003 SSBF. Owing to its systematic approach and comprehensive scope, the SSBF remains the prime data source for numerous recent studies in small business research (for example, Cassar et al. 2015; Cole and Sokolyk 2016; Dai et al. 2017; Han et al. 2017). The survey covers a randomly drawn sample of 4240 firms, ${ }^{3}$ which fall within the small business taxonomy, i.e., up to a maximum of 500 employees. These firms are distributed across all US regions and industries, excluding agricultural businesses, nonprofits, subsidiaries and government entities. To overcome bias due to disproportionate sampling and/or nonresponse, the SSBF provides sampling weights that render the data representative of the US small business population. As a standard practice, SSBF-based research fully accounts for these weights (e.g., Cole et al. 2004; Hainmueller and Xu 2013; DuGoff et al. 2014). We adhere to this practice for the estimation of all statistics and regression analyses. Furthermore, we exercise caution to include only the most recent loan applications, i.e., filed within 12 months prior to interviewing for the survey, as these applications best represent a small firm's marginal borrowing cost and availability of credit (Wu and Chua 2012). The final data set consists of 1326 loan applications, 1214 (112) of which were approved (rejected).

\subsection{Variables}

Our aim in this paper is to analytically examine incentives for small businesses to borrow from a lender, other than the one from which they most frequently purchase financial services, and evaluate the impact of this behavior on the availability of credit and loan contract terms. The principal financial services provider is termed by the SSBF as the "primary" financial institution, with all other institutions being considered as "nonprimary" financial institutions. The relationship with the primary financial institution features extensively as a reference point in much empirical work in relationship banking (e.g., Berger and Udell 1998; Berger et al. 2001; Saparito and Coombs 2013). Implicit in these studies is the assumption that such is the breadth and scope of a small firm's collaboration with the main financial services provider, it is unlikely to remain of a purely transactional nature (Ono et al. 2014). Consistent with prior work, we attend to the primary vs. nonprimary distinction and use the divide to capture variation across the main outcomes of the borrower-lender relationship. As shown in Table 2, the dependent variables in our study include Switching dummy, Approval, Spread, Maturity, Guaranty, Collateral, Collateral $I A R$, and Collateral PA.

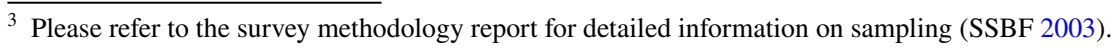




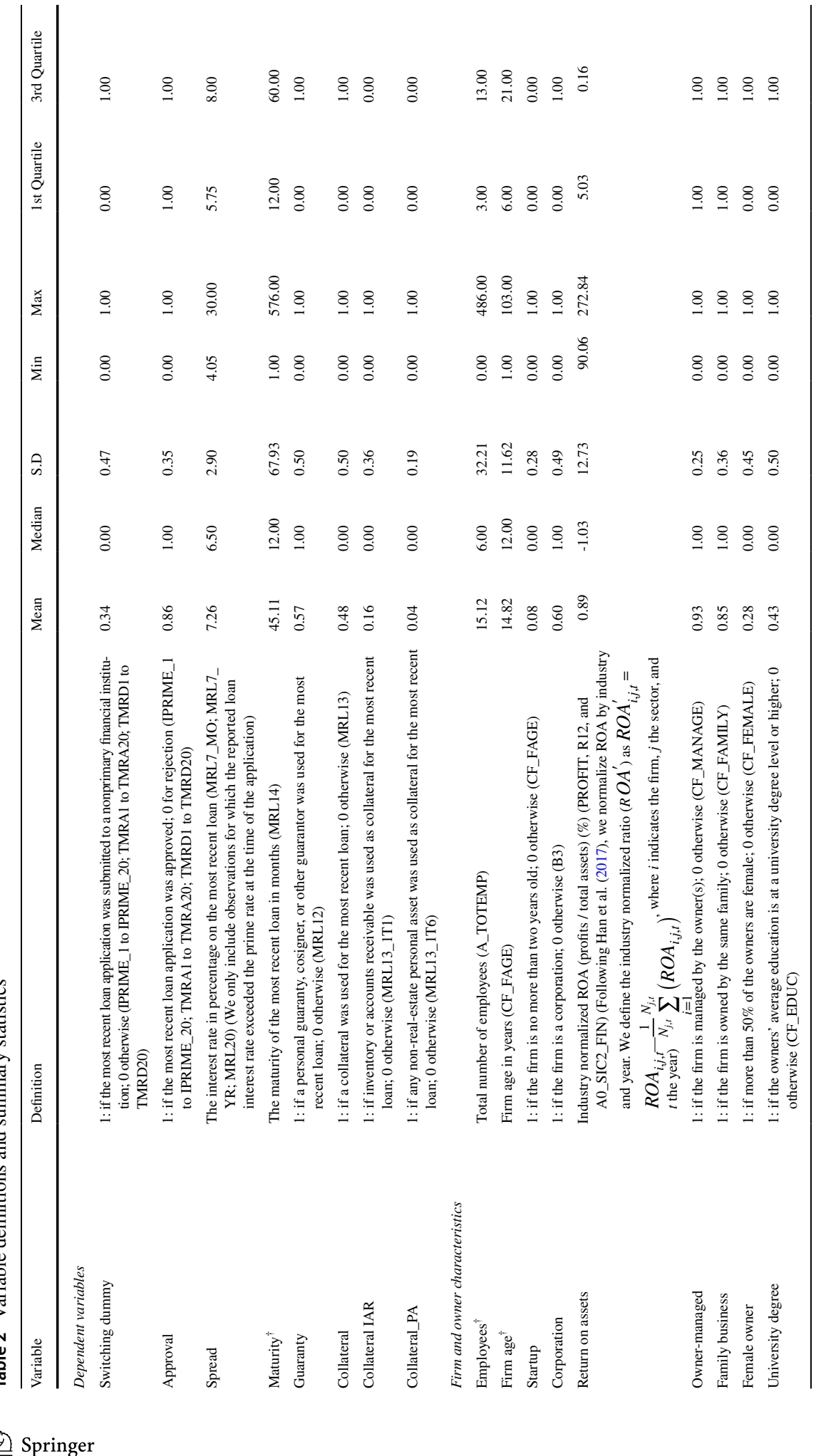




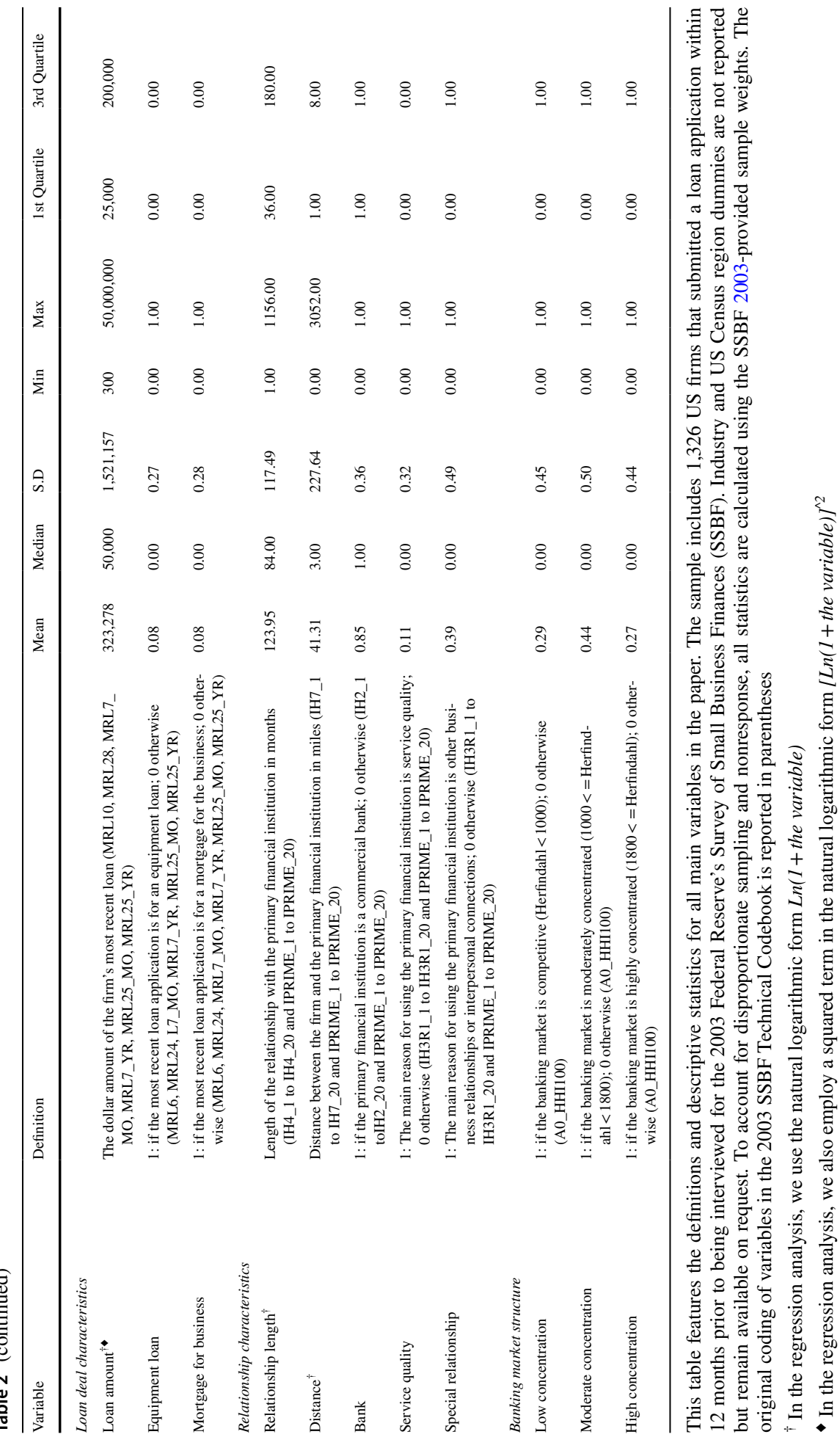


The selection of independent variables closely follows Cole et al. (2004). For a more systematic analysis, we classify these variables into four groups on the basis of characteristics relating to (1) firm and owner, (2) loan deals, (3) banking relationship, and (4) banking market structure. Table 2 reports the definitions and descriptive statistics for both dependent and independent variables. The median values sketch with clarity the profile of the typical firm in our sample. This is a family owned-and-managed enterprise, typically led by a male who lacks a university education. Notwithstanding the small size (six employees) and young age (12 years), this firm is likely to have attained a corporate status but, as evidenced by an ROA of $1.03 \%$, it struggles with profitability. Another distinctive characteristic is the banking mode, where the element of locality maps strongly onto our data. Specifically, the fact that the primary financial institution-predominantly a commercial bank-is associated with neither superior service quality nor with any special business or interpersonal ties, but is located only three miles away, suggests that it has been chosen mainly on the basis of convenience, which ties in with the overall resource scarcity of small businesses. The median length of the primary banking relationship is seven years, and the median loan application is for the amount of $\$ 50,000$.

\subsection{Univariate analysis}

Table 3 Panel A displays the proportion of firms exhibiting the switching behavior for each category of the independent dichotomous variables (X). Overall, it is noteworthy that firm, loan, and banking market characteristics all fail to support a systematic association on the basis of the switching dichotomy. However, we document that small businesses exhibit increased loyalty when the primary financial institution is a commercial bank, or in the presence of special business or personal relationships. Table 3 Panel B offers preliminary evidence on the impact of bank switching on small business borrowing: In general, this includes a lower loan approval rate, with the associated loans having both higher interest rates and longer maturities. Moreover, borrowing under higher information asymmetry is shown to decrease collateral pledging in the form of inventories and accounts receivable.

\section{Multivariate analysis}

In line with our aim for a symmetric understanding of bank switching, this section proceeds in two stages. First, we analyze the determinants inducing a small firm to submit a loan application to a nonprimary financial institution. Subsequently, we assess the impact of switching on the process of loan approval and key contractual terms attached to the new loan.

\subsection{Who is more likely to borrow from a nonprimary financial institution?}

To investigate a small firm's propensity to seek credit outside its primary bank, we follow Cole et al.'s (2004) comprehensive approach of variable selection and specify Eq. (1) as shown below: 


$$
\begin{aligned}
\operatorname{Ln}\left(\frac{p(\text { Switching dummy }=1)}{1-p(\text { Switching dummy }=1)}\right)= & \alpha_{0}+\alpha_{1} \times \text { Firm and owner characteristics }\left(X_{1 i}\right) \\
& +\alpha_{2} \times \text { Loan deal characteristics }\left(X_{2 i}\right) \\
& +\alpha_{3} \times \text { Relationship characteristics }\left(X_{3 i}\right) \\
& +\alpha_{4} \times \text { Banking market structure }\left(X_{4 i}\right) \\
& +\alpha_{4} \text { Industry and US Census region fixed effects }+\varepsilon_{i}
\end{aligned}
$$

where $p($ Switching dummy $=1)$ is the probability of borrowing from a nonprimary lender; $X$ includes a vector of relevant variables for each determinant category; and $i$ indicates the $\mathrm{i}$ th firm in the data set. The estimation is conducted via a logit regression that fully incorporates the SSBF 2003 survey weights.

The results from estimating Eq. (1) are presented in Table 4. Although the $\chi^{2}$ statistic indicates a good fit of the model, not all categories are equally important for the observed heterogeneity in switching. Among a number of firm and owner characteristics that could potentially exert an influence, we only find strong evidence in support of the role of firm size. Specifically, the larger the number of employees, the smaller the chance of borrowing from a nonprimary financial institution. The marginal effect is $-6.53 \%$, indicating that switching becomes $0.93 \%$ less likely for every additional employee. ${ }^{4}$ In addition, we observe an increased likelihood of switching for firms that have attained the status of a corporation; however, the resulting coefficient is significant only at the $10 \%$ level.

Turning to loan characteristics, we first document the irrelevance of the loan amount. By the inclusion of the loan amount squared term, we also rule out the possibility that this result is driven by a nonlinear association that our model fails to account for. We next investigate by loan type and register a systematic (positive) association of the switching likelihood with mortgage for business but not with an equipment loan. This variation is meaningful considering that a mortgage remains more resilient to information asymmetry than an equipment loan, as it generally requires minimal knowledge of the borrower's operations.

Relationship characteristics emerge as a category of variables with important explanatory power over bank switching. We first note the influence of bank and distance. As previously discussed, relationship lending is the technology most apt to unblock access to capital for informationally opaque organizations. In our model, the ability to mitigate information asymmetries by operationalizing soft information, the raison d'être of banks according to Boot (2000), is manifested by a significantly negative coefficient on bank and a marginal effect of $24.06 \%$, the highest of all covariates. With regard to distance, the convenience factor documented in our previous univariate analysis survives in the multivariate framework, yielding a significantly positive coefficient. The next set of variables, service quality and special relationship, provide insight about relationship aspects that are more subjective and less easily observed. In particular, we infer that an owner is inclined to stay in the relationship when perceiving quality in the services rendered or maintaining special business or interpersonal ties with the primary financial institution. That is, loan deals are evaluated in conjunction with the overall experience from the bank, and as part of broader social and business objectives. From this it follows that banks may dissuade small businesses from switching by improving aspects of the relationship other than the contractual terms of loans, which requires no deviation from a set credit policy.

${ }_{4} 0.93 \%=$ marginal effect $/(1+$ median value of employees $)=6.53 \% /(1+6)$. 
Table 3 Mean comparisons and univariate analysis

\begin{tabular}{|c|c|c|c|c|c|}
\hline \multirow{4}{*}{ Variable $(X)$} & \multicolumn{5}{|c|}{ Panel A: Mean comparisons by variable $(\mathrm{X})$ category } \\
\hline & \multirow{2}{*}{\multicolumn{2}{|c|}{$\begin{array}{l}\text { Proportion of } \\
\text { switching } \\
(X=1)\end{array}$}} & \multirow{2}{*}{\multicolumn{2}{|c|}{$(X=0)$}} & \multirow[t]{3}{*}{$\begin{array}{l}\text { Difference in } \\
\text { mean }(p \text {-value })\end{array}$} \\
\hline & & & & & \\
\hline & Mean & Std. dev & Mean & Std. dev & \\
\hline Corporation & 0.3137 & 0.4642 & 0.3706 & 0.4837 & 0.165 \\
\hline Startup & 0.4213 & 0.4973 & 0.3283 & 0.4698 & 0.185 \\
\hline Owner-managed & 0.3438 & 0.4752 & 0.2648 & 0.4427 & 0.277 \\
\hline Family business & 0.3471 & 0.4763 & 0.2737 & 0.4465 & 0.127 \\
\hline Female owner & 0.3473 & 0.4769 & 0.3350 & 0.4722 & 0.777 \\
\hline University degree & 0.3241 & 0.4684 & 0.3493 & 0.4771 & 0.521 \\
\hline Equipment loan & 0.3526 & 0.4800 & 0.3348 & 0.4721 & 0.798 \\
\hline Mortgage for business & 0.3742 & 0.4864 & 0.3327 & 0.4714 & 0.556 \\
\hline Bank & 0.2960 & 0.4567 & 0.5550 & 0.4984 & 0.000 \\
\hline Service quality & 0.2558 & 0.4375 & 0.3465 & 0.4761 & 0.110 \\
\hline Special relationship & 0.2547 & 0.4361 & 0.3873 & 0.4874 & 0.001 \\
\hline Low concentration & 0.3412 & 0.4748 & 0.3341 & 0.4719 & 0.868 \\
\hline Moderate concentration & 0.3190 & 0.4664 & 0.3496 & 0.4772 & 0.434 \\
\hline High concentration & 0.3585 & 0.4802 & 0.3279 & 0.4697 & 0.499 \\
\hline
\end{tabular}

Panel B: Mean comparisons by switching dummy

\begin{tabular}{|c|c|c|c|c|c|}
\hline \multirow[t]{2}{*}{ Variable (Y) } & \multicolumn{2}{|c|}{$\begin{array}{l}\text { Switching } \\
\text { dummy }=1\end{array}$} & \multicolumn{2}{|c|}{$\begin{array}{l}\text { Switching } \\
\text { dummy }=0\end{array}$} & \multirow[t]{2}{*}{$\begin{array}{l}\text { Difference in } \\
\text { mean (p-value) }\end{array}$} \\
\hline & Mean & Std. dev & Mean & Std. dev & \\
\hline Approval & 0.7962 & 0.4034 & 0.8908 & 0.3120 & 0.003 \\
\hline Spread & 8.0274 & 4.1580 & 6.9437 & 2.0899 & 0.007 \\
\hline Maturity $^{\dagger}$ & 3.6179 & 1.0531 & 3.0689 & 0.9233 & 0.000 \\
\hline Guaranty & 0.5497 & 0.4984 & 0.5787 & 0.4940 & 0.546 \\
\hline Collateral & 0.4484 & 0.4982 & 0.4901 & 0.5002 & 0.387 \\
\hline Collateral IAR & 0.0659 & 0.2486 & 0.1966 & 0.3977 & 0.000 \\
\hline Collateral PA & 0.0228 & 0.1495 & 0.0446 & 0.2066 & 0.141 \\
\hline
\end{tabular}

This table presents mean comparisons and univariate analyses of the main variables used in subsequent regressions. Panel A displays the proportion of switching by each category of the independent dichotomous variables (X). Panel B compares the mean values of the dependent variables (Y) based on the occurrence of switching. Accounting for disproportionate sampling and nonresponse, all statistics are calculated using the SSBF 2003-provided sample weights. The variables are defined in Table 2

$\dagger$ The variable is in the natural logarithmic form of $\operatorname{Ln}(1+$ the variable $)$ 
Table 4 Determinants of seeking credit from a nonprimary financial institution

\begin{tabular}{|c|c|c|}
\hline & Coef. (S.E.) & $\mathrm{dy} / \mathrm{dx}$ \\
\hline \multicolumn{3}{|c|}{ Firm and owner characteristics } \\
\hline Employees & $\begin{array}{l}-0.3044^{* * *} \\
(0.1155)\end{array}$ & $-6.53 \%$ \\
\hline Corporation & $\begin{array}{l}0.3664^{*} \\
(0.2220)\end{array}$ & $7.73 \%$ \\
\hline Firm age & $\begin{array}{l}-0.0388 \\
(0.1580)\end{array}$ & $-0.83 \%$ \\
\hline Startup & $\begin{array}{l}-0.0416 \\
(0.4379)\end{array}$ & $-0.89 \%$ \\
\hline Return on assets & $\begin{array}{l}0.0023 \\
(0.0059)\end{array}$ & $0.05 \%$ \\
\hline Owner-managed & $\begin{array}{l}0.0030 \\
(0.3245)\end{array}$ & $0.06 \%$ \\
\hline Family business & $\begin{array}{l}-0.1889 \\
(0.2794)\end{array}$ & $-4.15 \%$ \\
\hline Female owner & $\begin{array}{l}-0.1314 \\
(0.2136)\end{array}$ & $-2.79 \%$ \\
\hline University degree & $\begin{array}{l}0.1849 \\
(0.2050)\end{array}$ & $3.98 \%$ \\
\hline \multicolumn{3}{|l|}{ Loan deal characteristics } \\
\hline Loan amount & $\begin{array}{l}0.3753 \\
(0.5618)\end{array}$ & $8.05 \%$ \\
\hline Loan amount squared & $\begin{array}{l}-0.0274 \\
(0.0254)\end{array}$ & $-0.59 \%$ \\
\hline Equipment loan & $\begin{array}{l}-0.0934 \\
(0.3179)\end{array}$ & $-1.97 \%$ \\
\hline Mortgage for business & $\begin{array}{l}0.6928^{* *} \\
(0.3401)\end{array}$ & $16.13 \%$ \\
\hline \multicolumn{3}{|c|}{ Relationship characteristics } \\
\hline Relationship length & $\begin{array}{l}-0.0287 \\
(0.1031)\end{array}$ & $-0.61 \%$ \\
\hline Distance & $\begin{array}{l}0.1570^{* *} \\
(0.0661)\end{array}$ & $3.37 \%$ \\
\hline Bank & $\begin{array}{l}-1.0284^{* * *} \\
(0.2632)\end{array}$ & $-24.06 \%$ \\
\hline Service quality & $\begin{array}{l}-0.6785^{* *} \\
(0.3106)\end{array}$ & $-12.96 \%$ \\
\hline Special relationship & $\begin{array}{l}-0.7528^{* * *} \\
(0.2021)\end{array}$ & $-15.52 \%$ \\
\hline \multicolumn{3}{|l|}{ Banking market structure } \\
\hline HHIM & $\begin{array}{l}-0.0718 \\
(0.2281)\end{array}$ & $-1.54 \%$ \\
\hline HHIH & $\begin{array}{l}-0.1017 \\
(0.2742)\end{array}$ & $-2.16 \%$ \\
\hline \multicolumn{3}{|l|}{ Control variables } \\
\hline Prime rate & $\begin{array}{l}0.5432^{* *} \\
(0.2677)\end{array}$ & $11.65 \%$ \\
\hline Industry dummies & YES & YES \\
\hline Region dummies & YES & YES \\
\hline
\end{tabular}


Table 4 (continued)

\begin{tabular}{lll}
\hline & Coef. (S.E.) & $\mathrm{dy} / \mathrm{dx}$ \\
\hline Constant & -1.6388 \\
& $(3.3957)$ \\
Observations & 1283 \\
Pseudo R & $11.79 \%$ \\
Predicted probability & $31.14 \%$ \\
\hline
\end{tabular}

This table presents the analysis of the phenomenon of bank switching in small business. It displays the regression coefficients (Coef.) and marginal effects $(\mathrm{dy} / \mathrm{dx})$ based on weighted logit estimation of key determinants of choosing to submit the Most Recent Loan Application (MRLA) to a nonprimary financial institution. The dependent variable is the Switching dummy and the control variables also include industry and US Census region fixed effects. The robust standard errors are reported in parentheses. The analysis fully incorporates the SSBF 2003-provided sample weights. All variables have a lower than 5 variance inflation factor (VIF)

$* * *, * *, *$ denote confidence levels of $1 \%, 5 \%$ and $10 \%$, respectively

Finally, whether market concentration incentivizes banks to expend effort to overcome a small issuer's information opacity, as predicted by Petersen and Rajan (1995), or adversely affects the cost and availability of credit, as per the classical industrial organization prediction, HHI is a factor that should generally reflect on the switching decision. Nevertheless, none of these predictions map onto our data. Investigating the effect of a moderate as well as a high level of banking market concentration, our proxy variables generate insignificant coefficients. This result parallels that of Berger et al. (2005), who fail to establish banking market structure as an important driver of banking relationship exclusivity.

\subsection{The impact of bank switching on small business loans}

Having delineated the factors inducing small businesses to apply for loans from financial institutions other than their primary one, we now turn to the ex post effects of this behavior. According to our descriptive statistics, $34 \%$ of our sample firms ultimately engage in bank switching. As previously stated, this transition restores a greater degree of information asymmetry, with the basis of the loan deal becoming less relational and more transactional. What do switchers gain, and which benefits are likely to be forfeited in the process? We address these questions in the remaining portion of our analysis.

Methodologically, we use the Switching dummy among the regressors and assess its influence on various facets of the process of borrowing from a nonprimary financial institution. All covariates from Eq. (1) have been identified to enter into a lender's decision to finance a small firm (e.g., Berger et al. 2005; Cole and Sokolyk 2016; Han et al. 2017) and, therefore, they retain their position in the new model. In its general form, Eq. (2) can be expressed as follows: 


$$
\begin{aligned}
Y= & \alpha_{0}+\omega \times \text { Switching dummy }\left(D_{i}\right)+\alpha_{1} \times \text { Firm and owner characteristics }\left(X_{1 i}\right) \\
& +\alpha_{2} \times \text { Loan deal characteristics }\left(X_{2 i}\right)+\alpha_{3} \times \text { Relationship characteristics }\left(X_{3 i}\right) \\
& +\alpha_{4} \times \text { Banking market structure }\left(X_{4 i}\right)+\text { Industry and US Census region fixed effects }+\varepsilon_{i}
\end{aligned}
$$

where $Y$ draws from a pool of variables of small business loan outcomes (i.e., Approval, Spread, Maturity, Guaranty, Collateral, Collateral IAR, and Collateral PA); Switching dummy is our main explanatory variable of interest; $X$ includes a vector of variables for each category; and $i$ indicates the $i$ th firm in the data set.

In estimating Eq. (2), endogeneity is a plausible source of bias. As previously discussed, the decision to extend or terminate the relationship with the primary financial institution hinges upon the firm's assessment of the use the latter institution makes of its information advantage. In addition to nonrandom assignment, a number of confounding factors may jointly affect loan contract terms and a small firm's choice of lenders. For example, Uchida et al. (2012) document that loan officer turnover impairs the bank's ability to fulfill its role as a repository of information. Relatedly, Schoar (2012) factors in the personal side of relationship banking to argue that bonding with the branch personnel engenders superior banking outcomes, with borrowers expressing significantly fewer complaints about their banking relationship. Because these issues are peripheral to the SSBF objectives, there are no questions to gauge such information.

As with any survey, SSBF can support the construction of a limited number of variables, which significantly narrows the scope for identifying truly exogenous variables, i.e., having no effect on the availability and terms of credit, in order to satisfy the exclusion restriction. To overcome this limitation, we depart from the traditional instrumental variables framework and address endogeneity via two methods that are novel to the small business literature: the inverse-probability treatment weighting (IPTW) propensity score approach and entropy balancing. ${ }^{5}$ Both methods involve a twofold procedure by initially computing and assigning weights to the control group (i.e., small firms applying for a new loan from a primary financial institution) for the purpose of supporting subsequent regression estimation where the treatment variable (Switching dummy) features as an explanatory variable. In comparison to the widely used propensity score matching, these methods provide more insight and make efficient use of the available data, as (1) they estimate the effect of every covariate in the model as opposed to only that of the treatment variable, a feature desirable for the entirety of our estimations and even more so in analyses that have attracted little or no attention in the literature, such as the likelihood of pledging specific types of collateral; and (2) the covariate balance is attained in an inclusive manner (i.e., the control group no longer comprises a subset of the untreated observations), which is crucial for survey-based research. Moreover, in comparison to each other, entropy balancing can be viewed as a generalized form of propensity score weighting (Hainmueller 2012), with both methods aiming at the creation of a pseudo-sample that approximates data drawn from a random sample. Yet entropy balancing differs in that the covariate balance between treatment and control groups is attained in a manner unaffected by research design specifications required by IPTW (such as caliper, width, common support, or matching with or without replacement). Thus, by the joint use of the two methods in all subsequent analyses,

\footnotetext{
5 A more technical discussion and applications in the recent corporate finance research feature in Garrido et al. (2014) and Wilde (2017), respectively.
} 


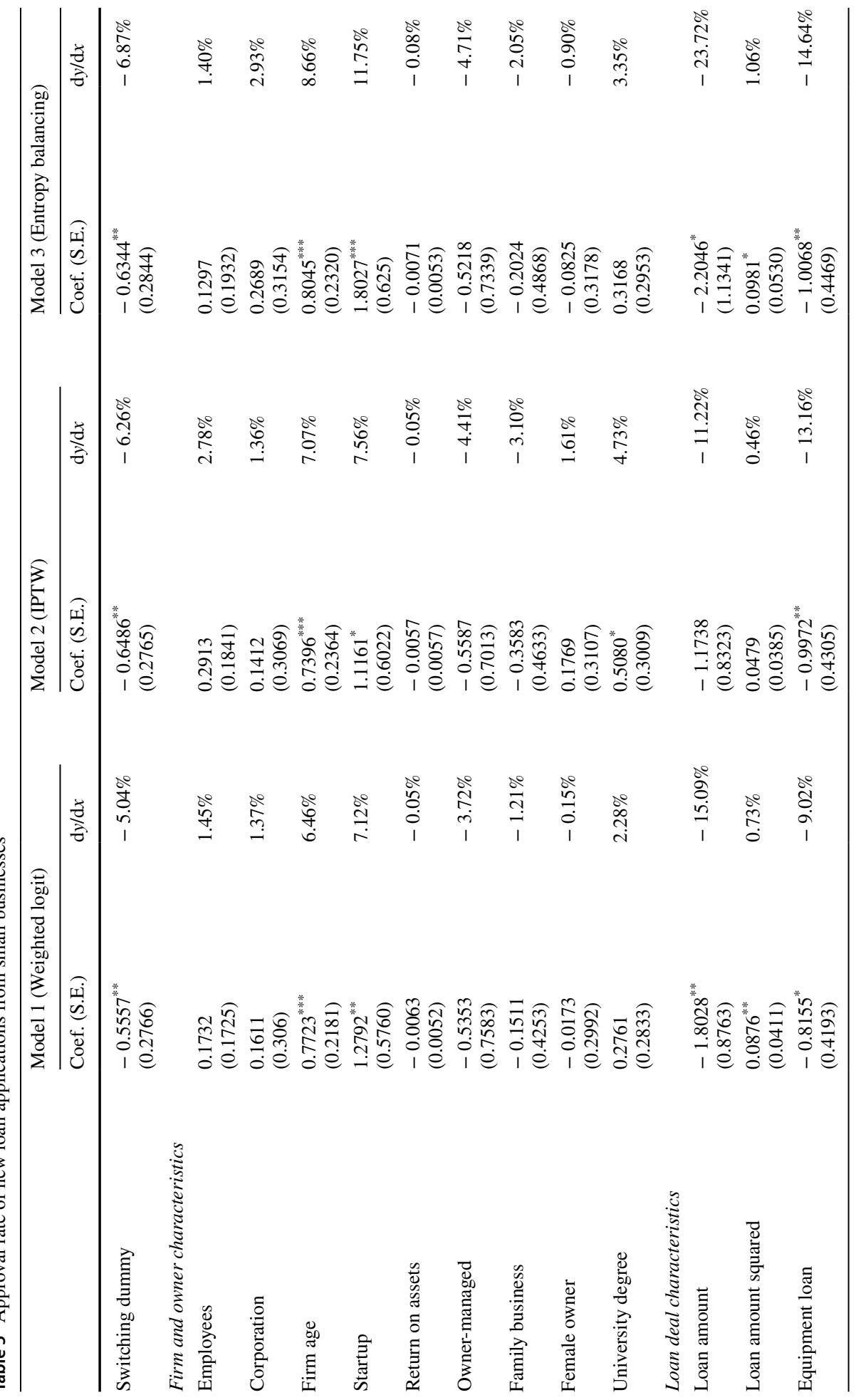




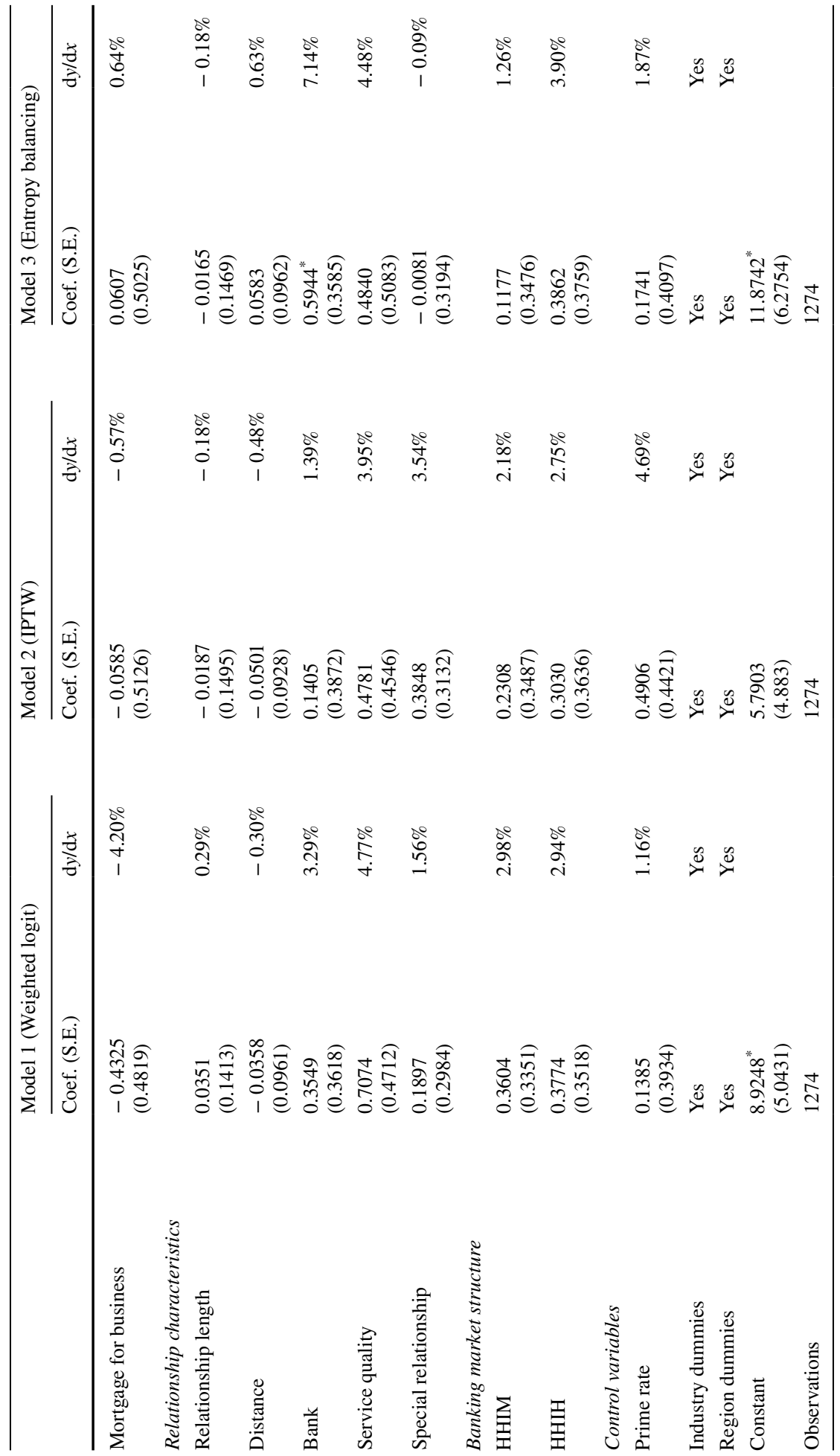




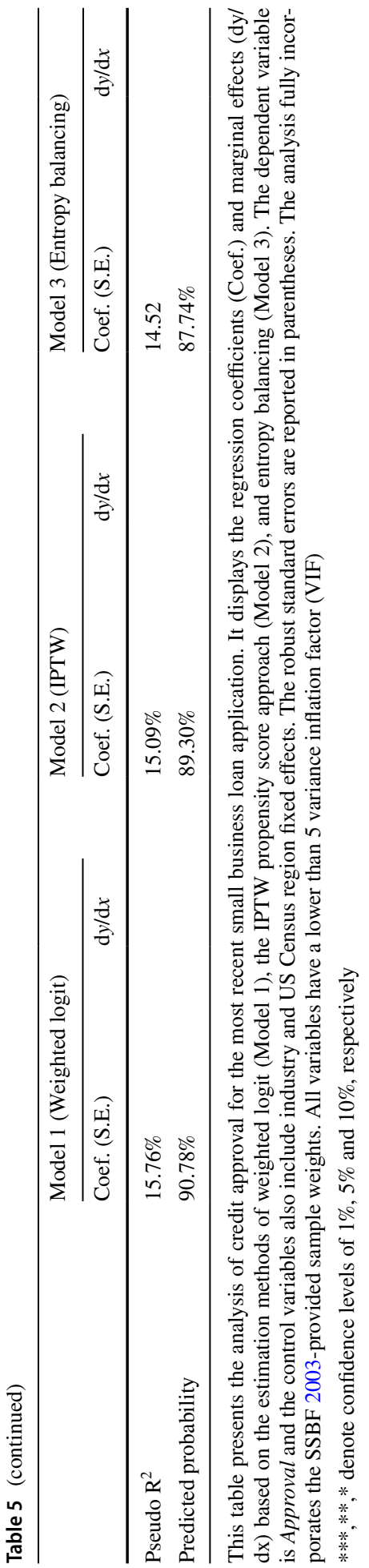


we subject our results to a rigorous robustness exercise. For the purpose of benchmarking, we juxtapose these results with those obtained from a parametric method (weighted least squares or weighted logit).

\subsubsection{Does borrowing from a nonprimary financial institution decrease the probability of loan approval?}

Compared to third-party financiers, the primary financial institution maintains a decisive information advantage, which allows for discrimination in credit allocation by the borrower's quality. Thus, while there is little economic rationale to refrain from lending to a firm that has manifested its creditworthiness over the course of a relationship, banks may actively pursue the limitation of exposure to borrowers of dubious quality by imposing credit rationing (as theoretically predicted by Stiglitz and Weiss 1981 and empirically validated by Farinha and Santos 2002). Regardless of the borrower's quality, however, informational opacity is the norm in small businesses, and this prevents a nonprimary financial institution from exhibiting a similar selective behavior. Instead, it is bound to apply lending standards that fully account for asymmetrical information, increasing the degree of uncertainty for new loan applications.

Table 5 presents the results of investigating the effect of bank switching on loan approval via weighted logit regression, IPTW, and entropy balancing estimation. All three methods confirm the frugality of nonprimary financial institutions in credit provision by means of a negative coefficient on the Switching dummy, which is statistically significant at the 5\% level. As indicated by the marginal effects, bank switching reduces the probability of loan approval by $6.26 \%$ (6.87\%) based on the IPTW (entropy balancing) method. In terms of the control variables, firm age and life-cycle stage are important in determining the approval rate. Loan deal characteristics also matter. In contrast, the outcome of a loan application is proven mostly irrelevant to relationship characteristics.

\subsubsection{Does borrowing from a nonprimary financial institution affect the borrowing cost?}

At this juncture of our analysis, we directly test for a possible lock-in effect in the relationship with the primary financial institution. If the latter uses its information advantage to unblock access to finance for the smallest of its business customers, then the associated loans should generally bear a lower interest rate than is available in the market. Conversely, a relatively high borrowing cost tends to be symptomatic of rent extraction and indicative of borrowers that have become locked into the relationship.

To explore how this core empirical question of relationship banking plays out in small business finance, we use the dependent variable Spread, the interest rate borne on the firm's most recent loan, and report the results of estimating Eq. (2) in Table 6. The positive association of bank switching with Spread is consistent across the models, suggesting that borrowing from the primary bank has a cost advantage. The economic perspective of this result can be inferred from the coefficient magnitudes of the IPTW and entropy balancing methods, which show higher interest rates by about 57 and 68 basis points, respectively. In support of Petersen and Rajan's (1994 and 1995) theoretical predictions that relationship 
Table 6 Cost of small business loans

\begin{tabular}{|c|c|c|c|}
\hline & $\begin{array}{l}\text { Model } 1 \text { (WLS) } \\
\text { Coef. (S.E.) }\end{array}$ & $\begin{array}{l}\text { Model 2(IPTW) } \\
\text { Coef. (S.E.) }\end{array}$ & $\begin{array}{l}\text { Model } 3 \text { (Entropy balancing) } \\
\text { Coef. (S.E.) }\end{array}$ \\
\hline Switching dummy & $\begin{array}{l}0.6678^{* *} \\
(0.3342)\end{array}$ & $\begin{array}{l}0.5682^{* *} \\
(0.2894)\end{array}$ & $\begin{array}{l}0.6807^{* *} \\
(0.3474)\end{array}$ \\
\hline \multicolumn{4}{|c|}{ Firm and owner characteristics } \\
\hline Employees & $\begin{array}{l}-0.2406^{* *} \\
(0.1076)\end{array}$ & $\begin{array}{l}-0.3233^{* * *} \\
(0.1256)\end{array}$ & $\begin{array}{l}-0.4210^{* * *} \\
(0.1556)\end{array}$ \\
\hline Corporation & $\begin{array}{l}0.3154 \\
(0.3108)\end{array}$ & $\begin{array}{l}0.4606 \\
(0.3328)\end{array}$ & $\begin{array}{l}0.7701^{* * *} \\
(0.3841)\end{array}$ \\
\hline Firm age & $\begin{array}{l}-0.2626 \\
(0.2302)\end{array}$ & $\begin{array}{l}-0.2651 \\
(0.2754)\end{array}$ & $\begin{array}{l}-0.1660 \\
(0.2934)\end{array}$ \\
\hline Startup & $\begin{array}{l}0.5352 \\
(0.7640)\end{array}$ & $\begin{array}{l}0.6874 \\
(0.7830)\end{array}$ & $\begin{array}{l}1.6407^{*} \\
(0.9691)\end{array}$ \\
\hline Return on assets & $\begin{array}{l}-0.0008 \\
(0.0082)\end{array}$ & $\begin{array}{l}0.0099 \\
(0.0160)\end{array}$ & $\begin{array}{l}-0.0015 \\
(0.0104)\end{array}$ \\
\hline Owner-managed & $\begin{array}{l}-0.5877 \\
(0.4659)\end{array}$ & $\begin{array}{l}-0.3609 \\
(0.5527)\end{array}$ & $\begin{array}{l}-0.8499 \\
(0.6297)\end{array}$ \\
\hline Family business & $\begin{array}{l}-0.0935 \\
(0.5049)\end{array}$ & $\begin{array}{l}-0.3783 \\
(0.7033)\end{array}$ & $\begin{array}{l}-0.4987 \\
(0.7482)\end{array}$ \\
\hline Female owner & $\begin{array}{l}-0.0808 \\
(0.2780)\end{array}$ & $\begin{array}{l}0.1517 \\
(0.3440)\end{array}$ & $\begin{array}{l}0.1456 \\
(0.3671)\end{array}$ \\
\hline University degree & $\begin{array}{l}-0.7903^{* * *} \\
(0.2699)\end{array}$ & $\begin{array}{l}-0.9366^{\text {*** }} \\
(0.2993)\end{array}$ & $\begin{array}{l}-1.0853^{\text {*** }} \\
(0.3623)\end{array}$ \\
\hline \multicolumn{4}{|l|}{ Loan deal characteristics } \\
\hline Loan amount & $\begin{array}{l}-3.5465^{* * *} \\
(0.9565)\end{array}$ & $\begin{array}{l}-3.6064^{* * *} \\
(1.0172)\end{array}$ & $\begin{array}{l}-4.7320^{* * *} \\
(1.4678)\end{array}$ \\
\hline Loan amount squared & $\begin{array}{l}0.1353^{* * *} \\
(0.0418)\end{array}$ & $\begin{array}{l}0.1378^{* * *} \\
(0.0451)\end{array}$ & $\begin{array}{l}0.1895^{* * *} \\
(0.0667)\end{array}$ \\
\hline Equipment loan & $\begin{array}{l}0.0578 \\
(0.4878)\end{array}$ & $\begin{array}{l}0.3067 \\
(0.5079)\end{array}$ & $\begin{array}{l}0.5068 \\
(0.6352)\end{array}$ \\
\hline Mortgage for business & $\begin{array}{l}0.5825 \\
(0.5553)\end{array}$ & $\begin{array}{l}0.5187 \\
(0.4857)\end{array}$ & $\begin{array}{l}0.2404 \\
(0.4912)\end{array}$ \\
\hline \multicolumn{4}{|c|}{ Relationship characteristics } \\
\hline Relationship length & $\begin{array}{l}-0.1188 \\
(0.1304)\end{array}$ & $\begin{array}{l}-0.1640 \\
(0.1651)\end{array}$ & $\begin{array}{l}-0.2178 \\
(0.195)\end{array}$ \\
\hline Distance & $\begin{array}{l}0.1492 \\
(0.1312)\end{array}$ & $\begin{array}{l}0.2019 \\
(0.1783)\end{array}$ & $\begin{array}{l}0.1662 \\
(0.1453)\end{array}$ \\
\hline Bank & $\begin{array}{l}-0.3473 \\
(0.3951)\end{array}$ & $\begin{array}{l}-0.1086 \\
(0.3883)\end{array}$ & $\begin{array}{l}-0.2039 \\
(0.4498)\end{array}$ \\
\hline Service quality & $\begin{array}{l}0.0510 \\
(0.3190)\end{array}$ & $\begin{array}{l}0.3016 \\
(0.3721)\end{array}$ & $\begin{array}{l}0.1467 \\
(0.4103)\end{array}$ \\
\hline Special relationship & $\begin{array}{l}0.6559^{* *} \\
(0.3244)\end{array}$ & $\begin{array}{l}0.9704^{* *} \\
(0.3903)\end{array}$ & $\begin{array}{l}0.9174^{*} \\
(0.4958)\end{array}$ \\
\hline \multicolumn{4}{|l|}{ Banking market structure } \\
\hline HHIM & $\begin{array}{l}0.6605^{* *} \\
(0.3293)\end{array}$ & $\begin{array}{l}1.0211^{* *} \\
(0.4084)\end{array}$ & $\begin{array}{l}1.4898^{* * *} \\
(0.4846)\end{array}$ \\
\hline НHIH & $\begin{array}{l}0.1672 \\
(0.2982)\end{array}$ & $\begin{array}{l}0.2605 \\
(0.3038)\end{array}$ & $\begin{array}{l}0.9027^{* *} \\
(0.4255)\end{array}$ \\
\hline
\end{tabular}


Table 6 (continued)

\begin{tabular}{llll}
\hline & $\begin{array}{l}\text { Model 1 (WLS) } \\
\text { Coef. (S.E.) }\end{array}$ & $\begin{array}{l}\text { Model 2(IPTW) } \\
\text { Coef. (S.E.) }\end{array}$ & $\begin{array}{l}\text { Model 3 (Entropy balancing) } \\
\text { Coef. (S.E.) }\end{array}$ \\
\hline $\begin{array}{llll}\text { Control variables } \\
\text { Prime rate }\end{array}$ & -0.3864 & -0.2715 & -0.5779 \\
& $(0.3670)$ & $(0.4591)$ & $(0.4512)$ \\
Industry dummies & Yes & Yes & Yes \\
Region dummies & Yes & Yes & Yes \\
Constant & $33.3839^{* * *}$ & $33.0549^{* * *}$ & $41.1215^{* * *}$ \\
& $(5.9729)$ & $(6.3766)$ & $(8.1546)$ \\
Observations & 873 & 873 & 873 \\
F-statistics & $2.45^{* * *}$ & $2.12^{* * *}$ & $2.86^{* * *}$ \\
R-squared & 0.2570 & 0.2601 & 0.3144 \\
Predicted y & 7.27 & 7.29 & 7.61 \\
\hline
\end{tabular}

This table presents the analysis of borrowing cost of small business loans. It displays the regression coefficients (Coef.) and marginal effects (dy/dx) based on weighted least squares (WLS) estimation (Model 1), the IPTW propensity score approach (Model 2), and entropy balancing (Model 3). The dependent variable is Spread and the control variables also include industry and US Census region fixed effects. The robust standard errors are reported in parentheses. The analysis fully incorporates the SSBF 2003-provided sample weights. All variables have a lower than 5 variance inflation factor (VIF)

$* * *, * * *$ denote confidence levels of $1 \%, 5 \%$ and $10 \%$, respectively

banking is beneficial to overcoming the problem of asymmetric information, small businesses are shown to be able to borrow more cheaply from the institution that possesses the largest amount of borrower-specific information. This evidence substantiates Ono et al.'s (2014) distinction between the primary financial institution, which is assumed to be a relational lender, and nonprimary lenders, treated as transactional lenders.

In addition, we note the influence of the loan amount and loan amount squared covariates. While both generate coefficients that attain all conventional levels of statistical significance, the signs are of opposite direction. Together, these results suggest a U-shaped effect of loan amount on borrowing cost. Furthermore, we obtain evidence cautioning that a special relationship with a financial services provider, because of business or interpersonal ties, generally serves to increase the cost of loans.

\subsubsection{Does borrowing from a nonprimary financial institution decrease loan maturity?}

Our next set of tests complements the evidence on borrowing cost by investigating whether the loan maturity offered by the primary financial institution is systematically different from that granted by arm's-length lenders. Posing another central tension in small business finance, short debt maturities are customary for informationally opaque organizations. Although a short-term loan contract provides scope for timely interventions as more borrower-specific information becomes available, it entails a lower degree of flexibility for small firms that could be impelled to forego investment opportunities with a longer life cycle (Ortiz-Molina and Penas 2008). Equipped with better insight about a borrower's 
Table 7 Maturity of small business loans

\begin{tabular}{|c|c|c|c|}
\hline & $\begin{array}{l}\text { Model } 1 \text { (WLS) } \\
\text { Coef. (S.E.) }\end{array}$ & $\begin{array}{l}\text { Model } 2 \text { (IPTW) } \\
\text { Coef. (S.E.) }\end{array}$ & $\begin{array}{l}\text { Model 3(Entropy balancing) } \\
\text { Coef. (S.E.) }\end{array}$ \\
\hline Switching dummy & $\begin{array}{l}0.5386^{* * *} \\
(0.0948)\end{array}$ & $\begin{array}{l}0.5138^{* * *} \\
(0.0846)\end{array}$ & $\begin{array}{l}0.5170^{* * *} \\
(0.0990)\end{array}$ \\
\hline \multicolumn{4}{|c|}{ Firm and owner characteristics } \\
\hline Employees & $\begin{array}{l}-0.0405 \\
(0.0408)\end{array}$ & $\begin{array}{l}0.0020 \\
(0.0462)\end{array}$ & $\begin{array}{l}-0.0130 \\
(0.0567)\end{array}$ \\
\hline Corporation & $\begin{array}{l}-0.0386 \\
(0.0931)\end{array}$ & $\begin{array}{l}-0.0491 \\
(0.1035)\end{array}$ & $\begin{array}{l}-0.0745 \\
(0.1152)\end{array}$ \\
\hline Firm age & $\begin{array}{l}0.0799 \\
(0.0676)\end{array}$ & $\begin{array}{l}0.0472 \\
(0.0740)\end{array}$ & $\begin{array}{l}0.0650 \\
(0.0858)\end{array}$ \\
\hline Startup & $\begin{array}{l}0.3103 \\
(0.1948)\end{array}$ & $\begin{array}{l}0.2600 \\
(0.2243)\end{array}$ & $\begin{array}{l}0.3310 \\
(0.2668)\end{array}$ \\
\hline Return on assets & $\begin{array}{l}0.0087^{*} \\
(0.0047)\end{array}$ & $\begin{array}{l}0.0102^{*} \\
(0.0058)\end{array}$ & $\begin{array}{l}0.0079 \\
(0.0057)\end{array}$ \\
\hline Owner-managed & $\begin{array}{l}-0.0493 \\
(0.1071)\end{array}$ & $\begin{array}{l}0.0233 \\
(0.1130)\end{array}$ & $\begin{array}{l}-0.1061 \\
(0.1237)\end{array}$ \\
\hline Family business & $\begin{array}{l}0.1930^{* *} \\
(0.0904)\end{array}$ & $\begin{array}{l}0.2436^{* *} \\
(0.1064)\end{array}$ & $\begin{array}{l}0.2700^{* * *} \\
(0.1253)\end{array}$ \\
\hline Female owner & $\begin{array}{l}0.0376 \\
(0.0850)\end{array}$ & $\begin{array}{l}0.0951 \\
(0.0985)\end{array}$ & $\begin{array}{l}0.0738 \\
(0.1129)\end{array}$ \\
\hline University degree & $\begin{array}{l}-0.1035 \\
(0.0776)\end{array}$ & $\begin{array}{l}-0.0835 \\
(0.0912)\end{array}$ & $\begin{array}{l}-0.1442 \\
(0.1059)\end{array}$ \\
\hline \multicolumn{4}{|c|}{ Loan deal characteristics } \\
\hline Loan amount & $\begin{array}{l}0.5669^{* * *} \\
(0.1919)\end{array}$ & $\begin{array}{l}0.4115^{* *} \\
(0.1949)\end{array}$ & $\begin{array}{l}0.8563^{* * *} \\
(0.2629)\end{array}$ \\
\hline Loan amount squared & $\begin{array}{l}-0.0240^{* * *} \\
(0.0080)\end{array}$ & $\begin{array}{l}-0.0193^{* *} \\
(0.0082)\end{array}$ & $\begin{array}{l}-0.0401^{\text {*** }} \\
(0.0116)\end{array}$ \\
\hline Equipment loan & $\begin{array}{l}0.7531^{* * *} \\
(0.1290)\end{array}$ & $\begin{array}{l}0.6503^{* * *} \\
(0.1388)\end{array}$ & $\begin{array}{l}0.6272^{* * * *} \\
(0.1382)\end{array}$ \\
\hline Mortgage for business & $\begin{array}{l}1.3270^{* * *} \\
(0.1960)\end{array}$ & $\begin{array}{l}1.3328^{* * *} \\
(0.2115)\end{array}$ & $\begin{array}{l}1.0331^{* * *} \\
(0.2497)\end{array}$ \\
\hline \multicolumn{4}{|c|}{ Relationship characteristics } \\
\hline Relationship length & $\begin{array}{l}0.0217 \\
(0.0422)\end{array}$ & $\begin{array}{l}0.0896^{* *} \\
(0.0456)\end{array}$ & $\begin{array}{l}0.0304 \\
(0.0526)\end{array}$ \\
\hline Distance & $\begin{array}{l}-0.0067 \\
(0.0300)\end{array}$ & $\begin{array}{l}0.0114 \\
(0.0327)\end{array}$ & $\begin{array}{l}0.0097 \\
(0.0336)\end{array}$ \\
\hline Bank & $\begin{array}{l}0.3201^{* *} \\
(0.1299)\end{array}$ & $\begin{array}{l}0.4098^{\text {*** }} \\
(0.1405)\end{array}$ & $\begin{array}{l}0.3617^{* * * *} \\
(0.1411)\end{array}$ \\
\hline Service quality & $\begin{array}{l}-0.1313 \\
(0.1059)\end{array}$ & $\begin{array}{l}-0.1096 \\
(0.1236)\end{array}$ & $\begin{array}{l}-0.1406 \\
(0.1591)\end{array}$ \\
\hline Special relationship & $\begin{array}{l}0.0288 \\
(0.0814)\end{array}$ & $\begin{array}{l}0.0337 \\
(0.0909)\end{array}$ & $\begin{array}{l}0.0667 \\
(0.1000)\end{array}$ \\
\hline \multicolumn{4}{|l|}{ Banking market structure } \\
\hline HHIM & $\begin{array}{l}-0.2746^{* * *} \\
(0.0908)\end{array}$ & $\begin{array}{l}-0.3459^{* * *} \\
(0.0996)\end{array}$ & $\begin{array}{l}-0.3138^{* * *} \\
(0.1113)\end{array}$ \\
\hline НHIH & $\begin{array}{l}-0.2354^{* *} \\
(0.1081)\end{array}$ & $\begin{array}{l}-0.3720^{* * *} \\
(0.1174)\end{array}$ & $\begin{array}{l}-0.3279^{* *} \\
(0.1337)\end{array}$ \\
\hline
\end{tabular}


Table 7 (continued)

$\begin{array}{lll}\text { Model 1 (WLS) } & \text { Model 2 (IPTW) } & \text { Model 3(Entropy balancing) } \\ \text { Coef. (S.E.) } & \text { Coef. (S.E.) } & \text { Coef. (S.E.) }\end{array}$

Control variables

$\begin{array}{llll}\text { Prime rate } & -0.1243 & -0.0190 & -0.0862 \\ \text { Industry dummies } & (0.0971) & (0.1126) & (0.1226) \\ \text { Region dummies } & \text { Yes } & \text { Yes } & \text { Yes } \\ \text { Constant } & \text { Yes } & \text { Yes } & \text { Yes } \\ \text { Observations } & -0.1787 & -0.0028 & -1.3428 \\ \text { F-statistics } & (1.1869) & (1.1984) & (1.5274) \\ \text { R-squared } & 1107 & 1107 & 1107 \\ \text { Predicted y } & 7.14^{* * *} & 7.28^{* * *} & 5.85^{* * *} \\ & 0.3598 & 0.3626 & 0.3437 \\ \end{array}$

This table presents the analysis of the maturity of small business loans. It displays the regression coefficients (Coef.) and marginal effects (dy/dx) based on weighted least squares (WLS) estimation (Model 1), the IPTW propensity score approach (Model 2), and entropy balancing (Model 3). The dependent variable is Maturity and the control variables also include industry and US Census region fixed effects. The robust standard errors are reported in parentheses. The analysis fully incorporates the SSBF 2003-provided sample weights. All variables have a lower than 5 variance inflation factor (VIF).

$* * *, * *, *$ denote confidence levels of $1 \%, 5 \%$ and $10 \%$, respectively

current standing and prospects, the primary financial institution is generally expected to concede a longer maturity.

To investigate the relationship between loan maturity and borrowing from nonprimary sources, we use the dependent variable Maturity, the length of the most recent loan in months, and report the results of estimating Eq. (2) in Table 7. Inconsistently with theory, we present clear evidence that if a firm borrows from a nonprimary financial institution, the maturity becomes longer. All three methods estimate an increase in the length of the loan contract by approximately two months. In conjunction with our previously reported evidence, this might be interpreted as an advantage nonprimary financial institutions offer with the aim of countering the adverse effects of a stricter credit approval process and higher borrowing costs.

\subsubsection{Does borrowing from a nonprimary financial institution increase the need for loan guaranty and collateral?}

The role of collateral has also attracted significant attention from studies focused on credit-rationing issues. Bester (1985) and Besanko and Thakor (1987) explicitly identify the pledging of various types of collateral (ranging from accounts receivable and inventory to owners' personal assets) as a sorting mechanism that banks frequently employ to gauge borrowers' quality. The underlying assumption is that only good borrowers are able to satisfy this requirement. Because information asymmetries intensify the need for signaling creditworthiness, collateral pledging is predominantly met in the context of small businesses (Pozzolo 2004). At the same time, not all entrepreneurs have equal access to collateral, which, considering the resource scarcity of small organizations, is likely to be the case even when a pipeline of positive NPV projects is available. A common means by which 


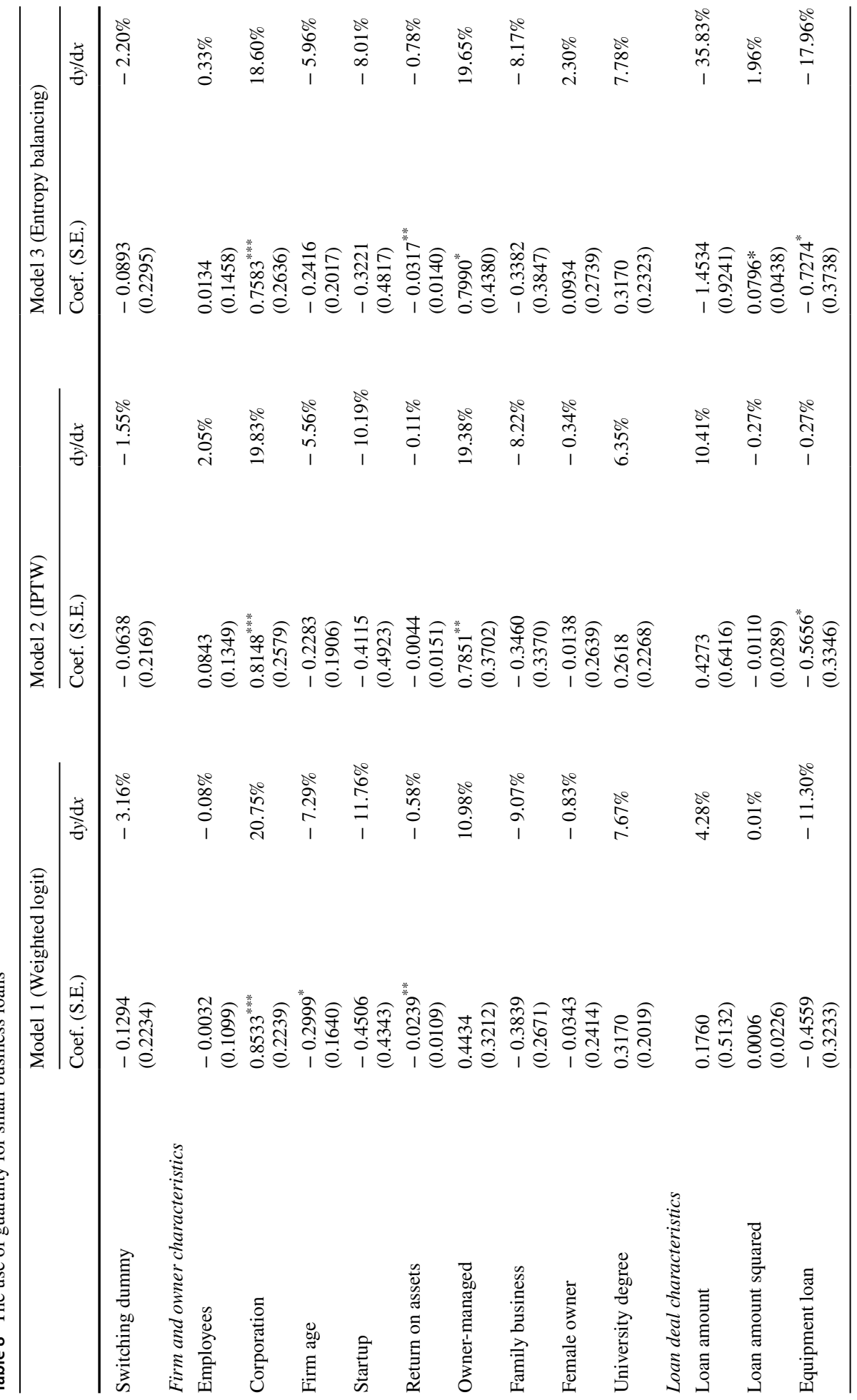




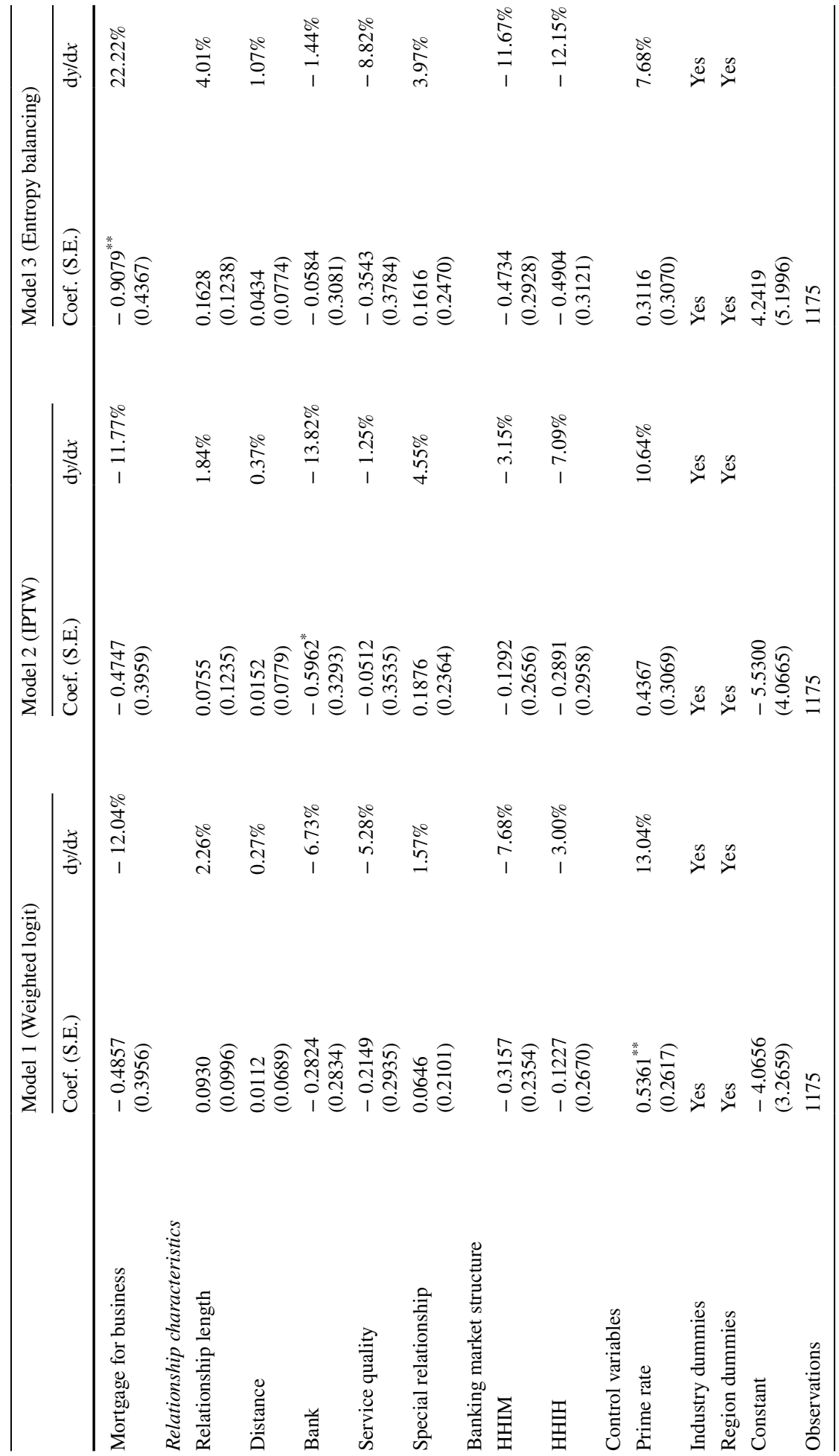




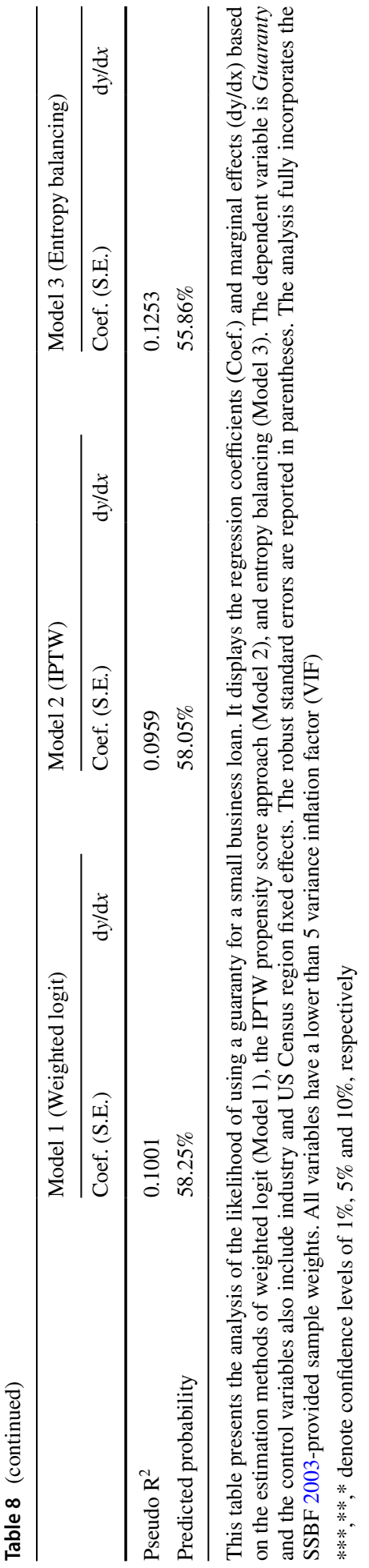




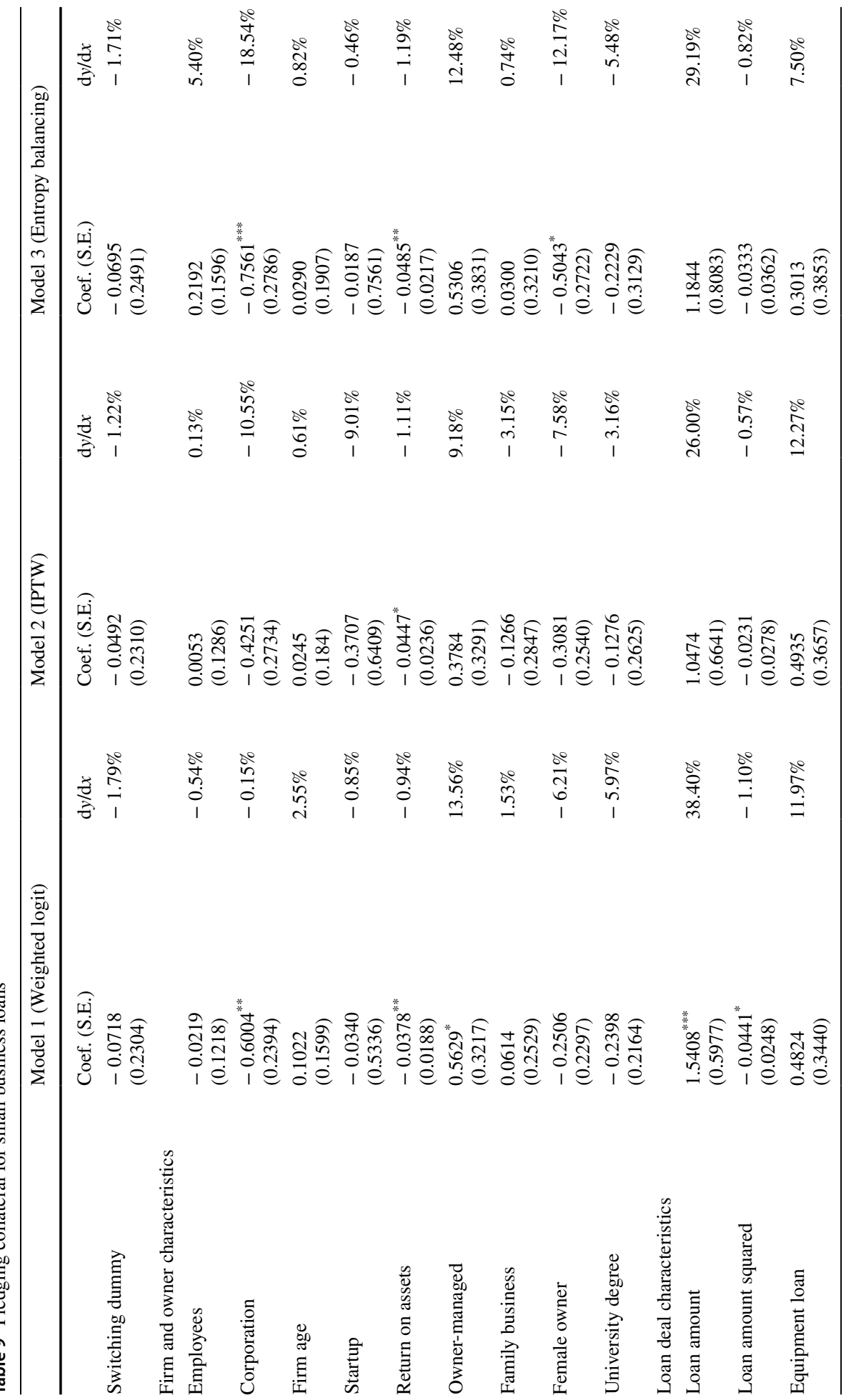




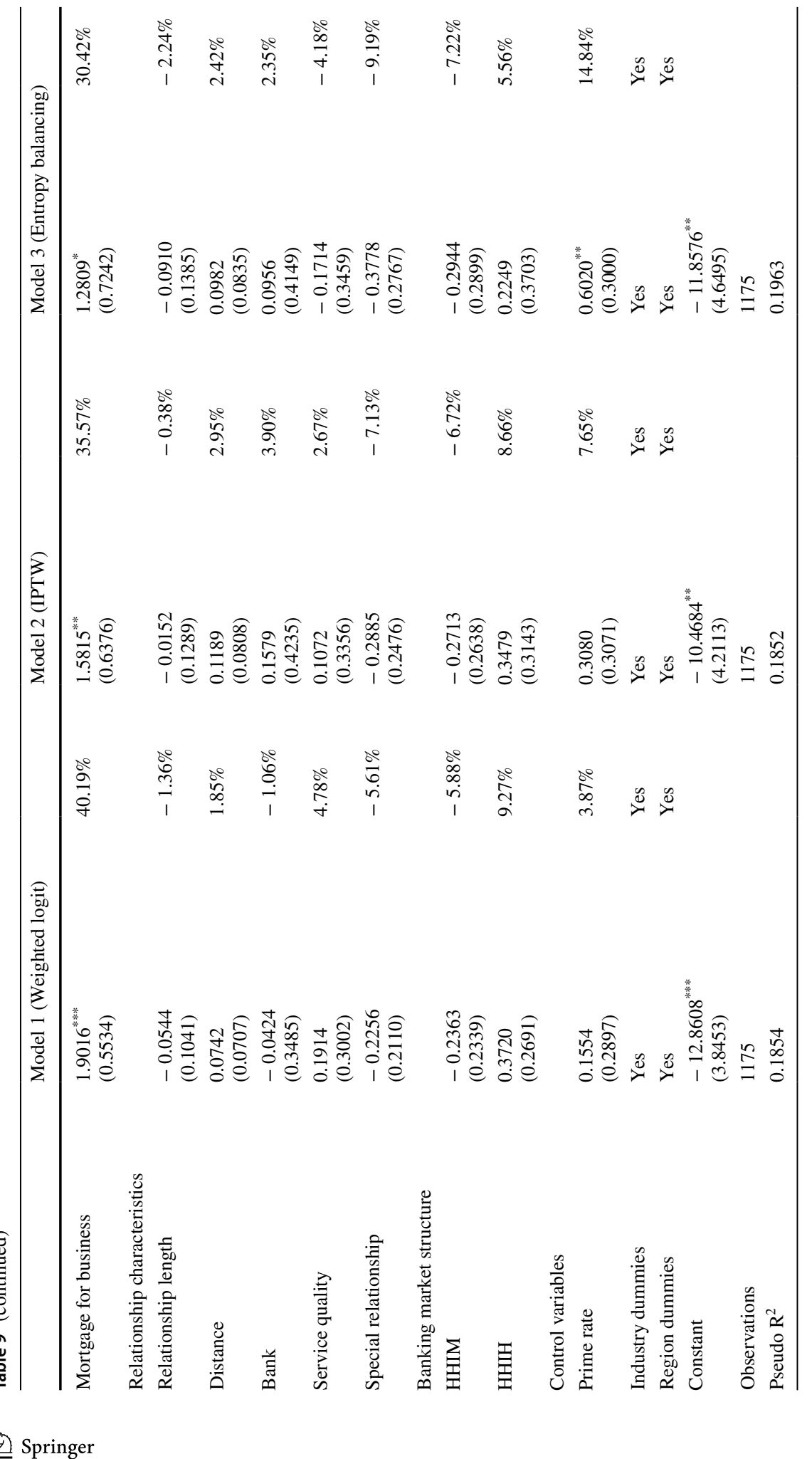




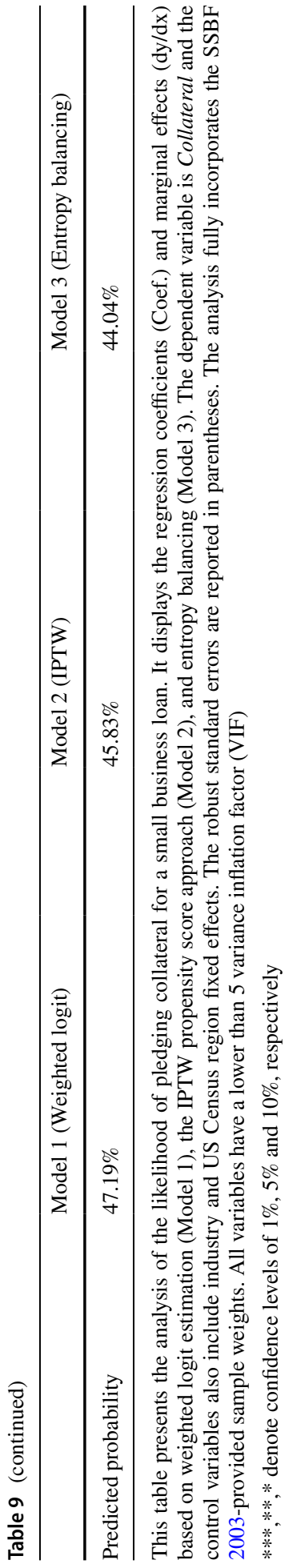




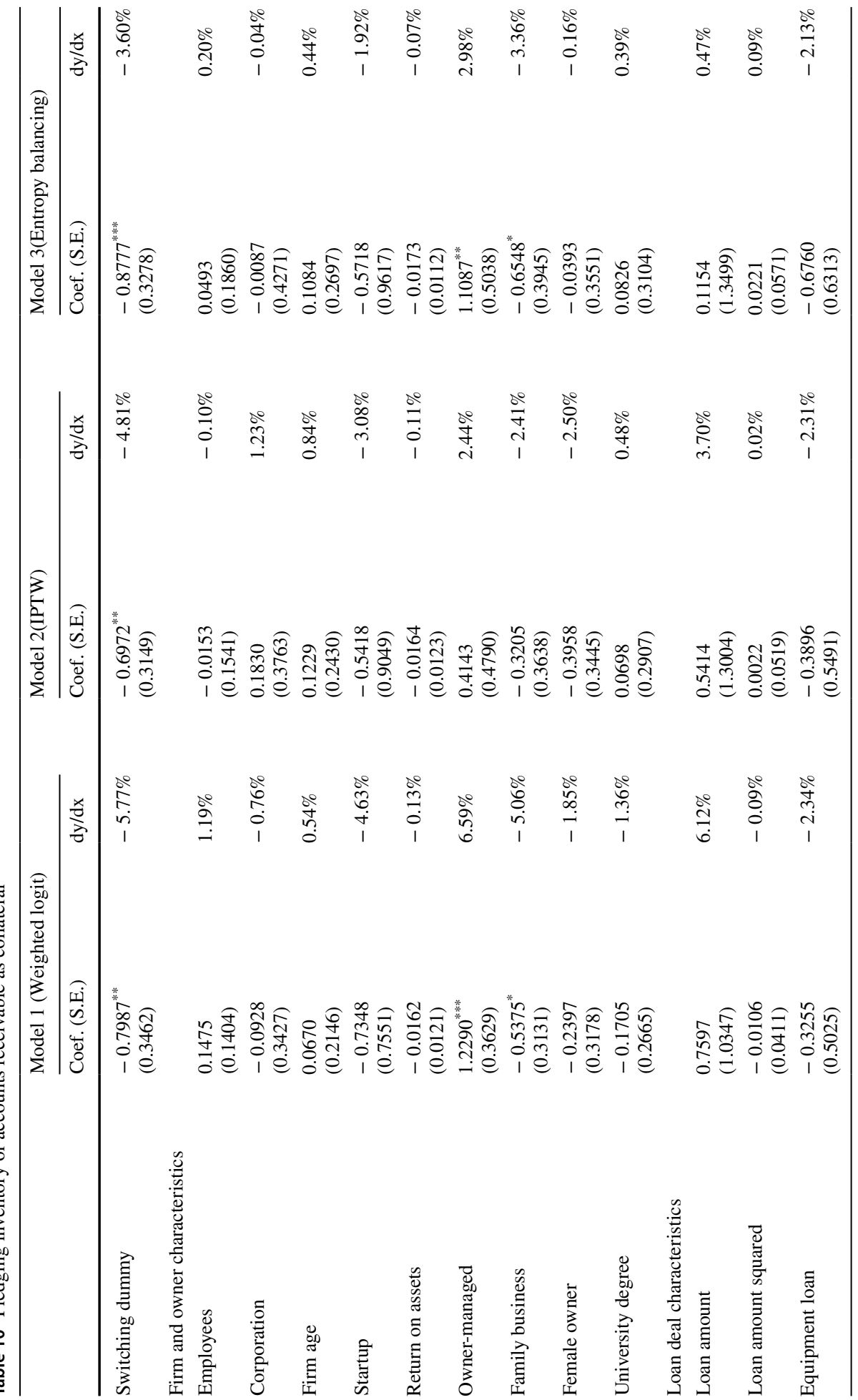




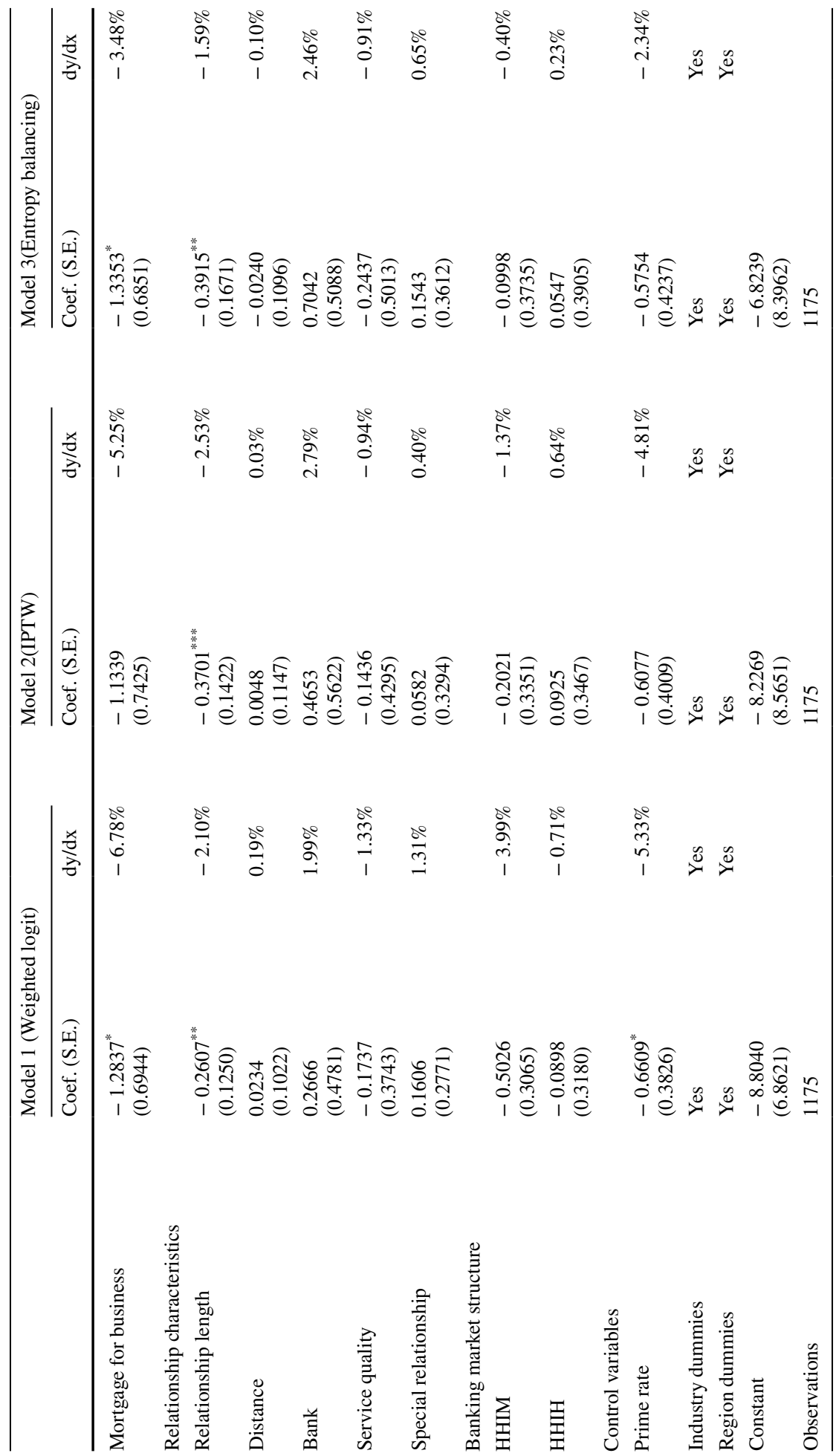




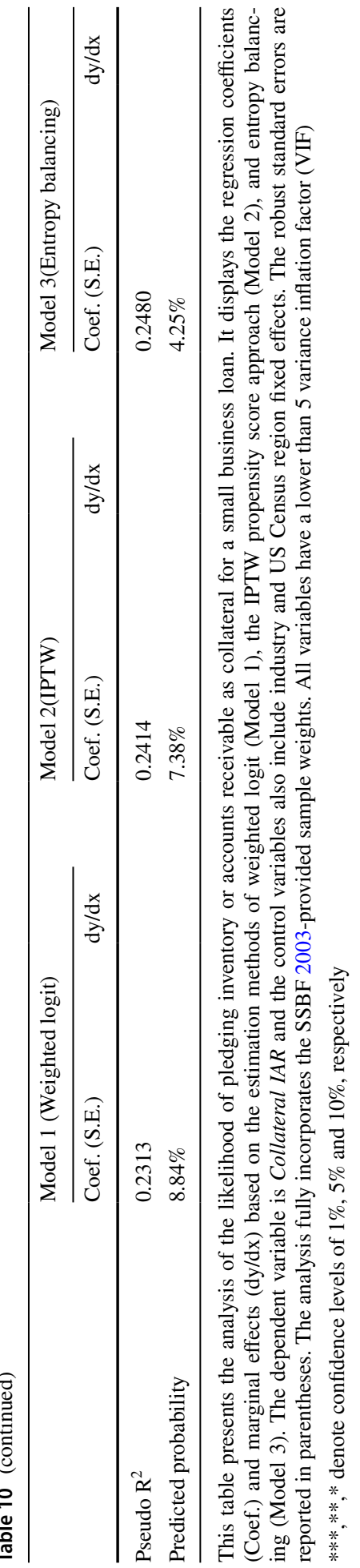




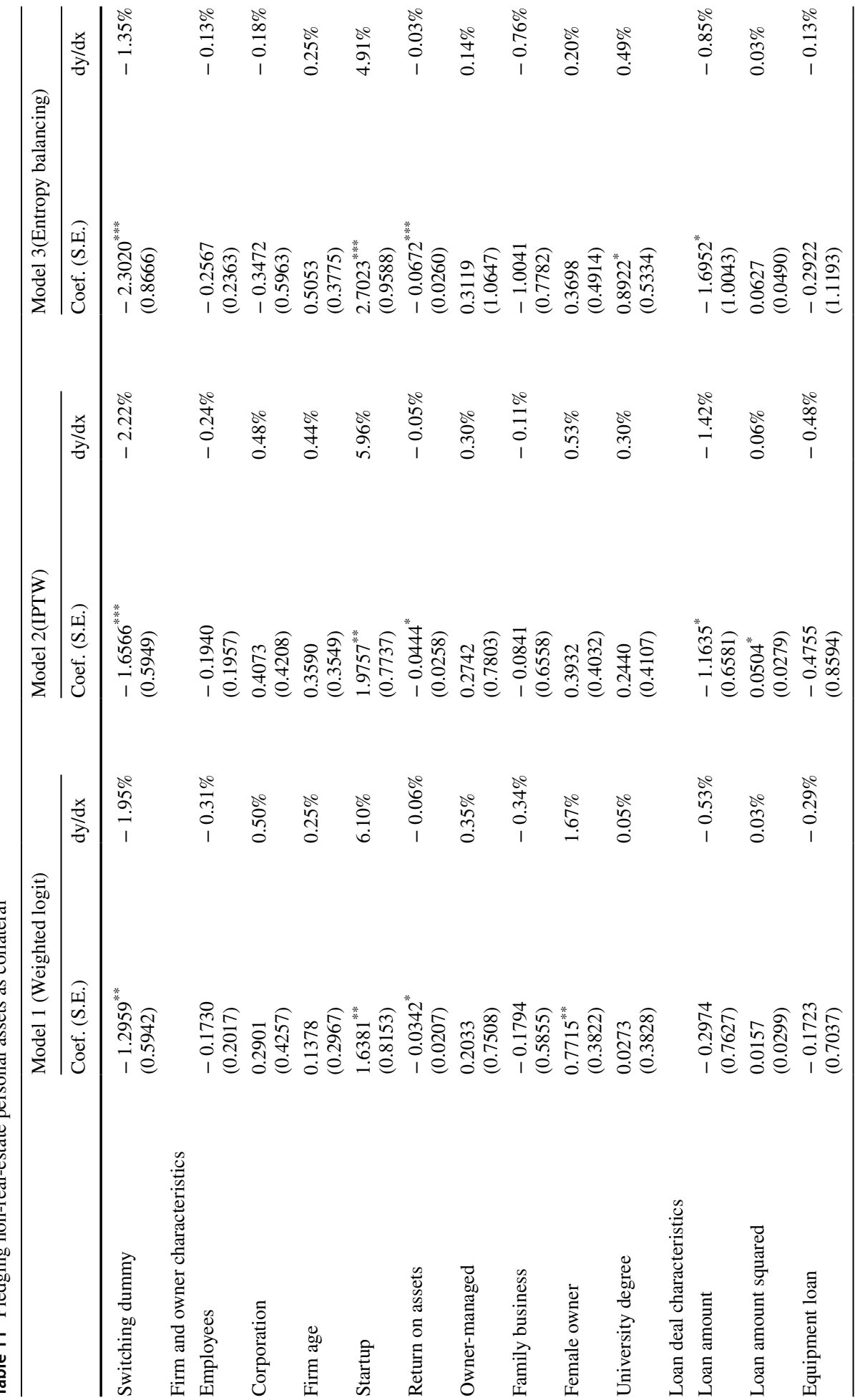




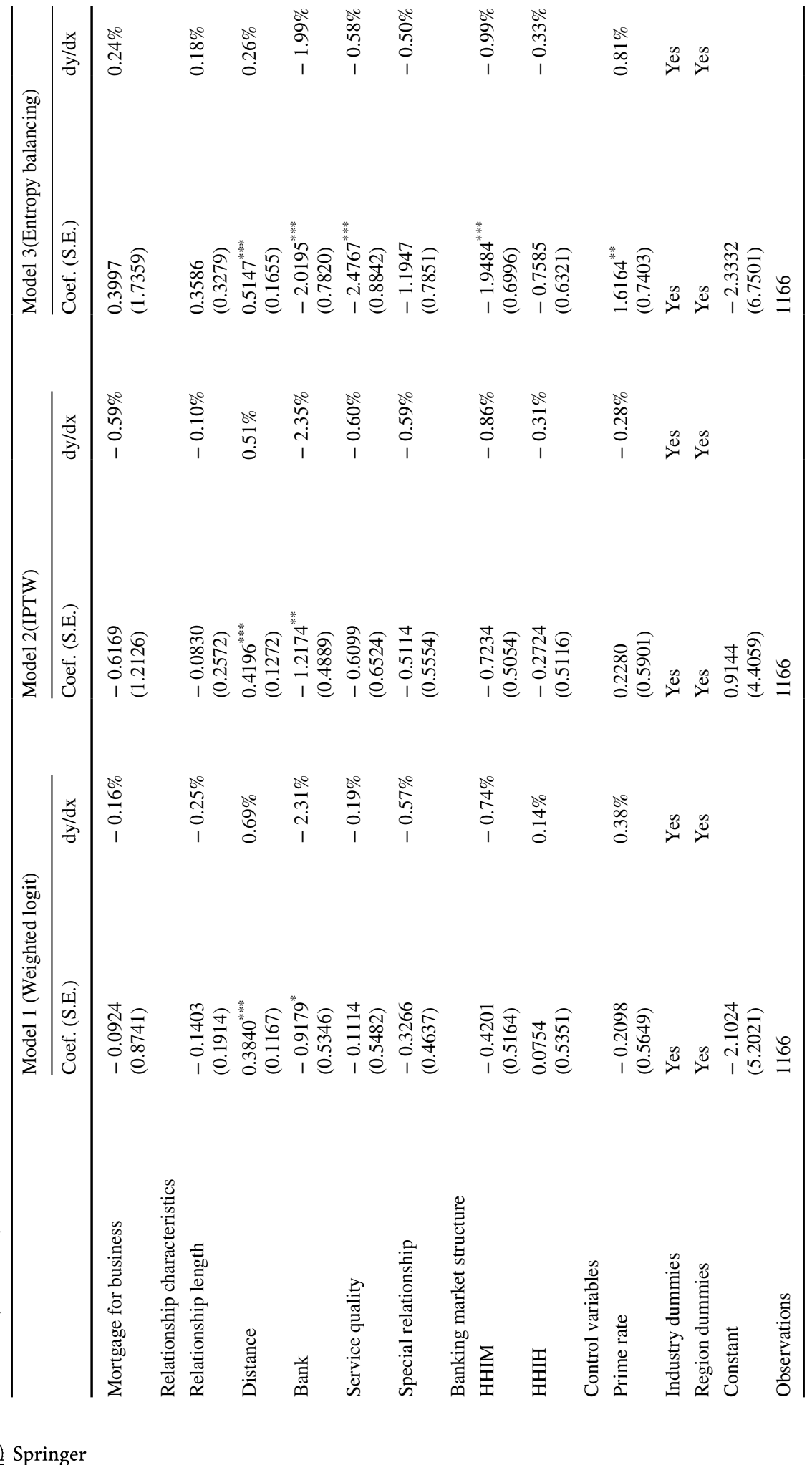




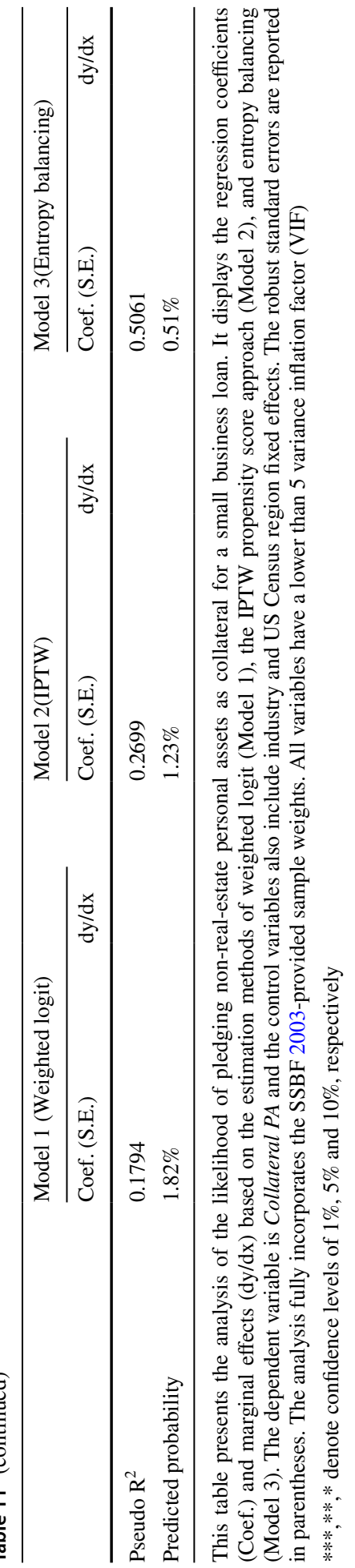


entrepreneurs will attempt to overcome this deficiency is through the use of a guaranty, i.e., a third party's declaration of willingness to service the debt obligation in the event of default. Such guarantees may either act as substitutes or in some cases come in addition to any collateral required. According to our sample descriptives, the proportions of small firms with the need to pledge collateral or use a guaranty in order to secure a loan are $48 \%$ and $57 \%$, respectively.

Based on the above, it is anticipated that such mechanisms of mitigating borrowerspecific uncertainty are in less (more) demand when a loan application is submitted to a relational (transactional) lender. We test the effect of switching on the likelihood of using a guaranty as well as pledging collateral, and present evidence in Tables 8 and 9 (respectively) that fails to support either association. As shown, the coefficient on the Switching dummy remains insignificant, a result invariant to the estimation method used. While this is surprising, we extend our investigation to capture potential variation residing at the level of collateral type.

\subsubsection{Does borrowing from a nonprimary financial institution affect the collateral type?}

Not all collateral types are equally influenced by borrowers' information environment. For some (e.g., a piece of real estate), competitive forces can readily provide a market value. Yet it is precarious to determine the value of other assets a priori. The difficulty lies in the fact that the valuation process requires input from sources that might be characterized by substantial uncertainty themselves. Such is the case when a small business owner pledges assets that are inherently tied to their business or broader set of possessions. Conceivably, these assets should do little to level the informational playing field, and therefore appear less likely to constitute an acceptable type of collateral for nonprimary lenders. Owing to the richness of the SSBF data, our study is one of the very few, if not the only one, to empirically validate this conjecture. With this aim, we associate bank switching with the probability of pledging inventory or accounts receivable as collateral (Collateral IAR) in Table 10, and with the likelihood of pledging owners' personal non-real-estate assets ( $\mathrm{Col}$ lateral PA) in Table 11. Both analyses convey insight suppressed by previous estimation treating collateral as a homogeneous category. Specifically, pledging inventory or accounts receivable is shown to be significantly less probable when submitting a loan application to a transactional lender that lacks critical knowledge of the borrower's operations. Likewise, pledging collateral in the form of owners' personal non-real-estate assets is inversely related to bank switching as, in this case, the information asymmetry extends to issues of personal integrity and trustworthiness. Evidently the type of collateral matters and can expand a small firm's choice of lenders, but only when it is least sensitive to the information differential between the primary and nonprimary financial institutions.

\section{Concluding remarks}

This study investigates the determinants and implications of bank switching in the area of small businesses. In our research design, the small firm's borrowing decision oscillates between two axes: (1) the primary financial institution, which maintains an informational advantage and provides relationship-based lending; and (2) nonprimary financial 
institutions, which operate at arm's length and issue loans on a transactional basis. Switching from the former source of finance to the latter is to effectively opt out from relationship banking, foregoing the time and cost committed to bridge the informational wedge with the main bank. The economic justification lies in the recognition that a suboptimal loan deal is preferable to succumbing to the rent-extracting trajectory of a relationship dominated by the holdup problem. Consequently, our study is of interest for small firms evaluating an incumbent relationship, banks aiming to enhance customer loyalty, and the broader academic debate on the value added of relationship banking.

In assessing the likelihood of soliciting credit from a nonprimary financial institution, we augment our prediction model with variables new to the research of the switching decision (owner characteristics, market structure, relationship features) and use a comprehensive sample of US firms that, unlike previous studies, excludes organizations that do not belong to the small business taxonomy. Our main findings are summarized as follows. The smaller a firm's size, the greater the likelihood of borrowing from a nonprimary financial institution. Banks maintain a comparative advantage in customer retention compared to nonbank financiers. However, when a bank's ability to act as an information repository is less important, such as in the provision of mortgages, there is a strong likelihood of switching. Relationship features, including the physical proximity to the primary financial institution, service quality, and any other special business or interpersonal relationships, exhibit high marginal effects and account for most of the remaining variation. The clear implication of these results is that banks are capable of discouraging switching by investing in the relationship per se and enhancing overall customer experience. Next, we scrutinize loans issued from transactional lenders and report a higher interest rate as well as a lower approval likelihood, consistent with the respective predictions of Berger and Udell (2002) and Stiglitz and Weiss (1981) about the cost savings of relationship banking and the occurrence of credit rationing outside of it. The main advantage of transactional lenders relates to loan maturity, approximately two months longer, while they also appear less likely to demand collateral in the form of accounts receivable, inventory or non-real-estate personal assets. Jointly, our results delineate the costs and benefits of switching, refute the widely invoked holdup problem and conclude that switching may be economically warranted on noncost considerations.

As is typical of survey-based studies, data availability creates some limitations. Financial contracting theory attributes an important monitoring role to loan covenants, and in a market of lenders with different access to borrower-specific information, the attached terms are likely to vary in the cross-section. Unfortunately, we are unable to test the effect of switching on loan covenants, as the relevant information falls outside the scope of the SSBF. Another limitation relates to the cross-sectional nature of the data, which precludes an analysis of long-term effects. Follow-on research with access to proprietary data is necessary to discern the effects of these additional dimensions.

Acknowledgements The authors are grateful to Professor Cheng-Few Lee (the Editor) and two anonymous reviewers for their helpful comments.

\section{Declarations}

Conflict of interest The authors declare that they have no conflict of interest.

Open Access This article is licensed under a Creative Commons Attribution 4.0 International License, which permits use, sharing, adaptation, distribution and reproduction in any medium or format, as long as you give appropriate credit to the original author(s) and the source, provide a link to the Creative Commons 
licence, and indicate if changes were made. The images or other third party material in this article are included in the article's Creative Commons licence, unless indicated otherwise in a credit line to the material. If material is not included in the article's Creative Commons licence and your intended use is not permitted by statutory regulation or exceeds the permitted use, you will need to obtain permission directly from the copyright holder. To view a copy of this licence, visit http://creativecommons.org/licenses/by/4.0/.

\section{References}

Ang JS (1991) Small business uniqueness and the theory of financial management. J Small Bus 1:1-13

Angelini P, Di Salvo R, Ferri G (1998) Availability and cost of credit for small businesses: customer relationships and credit cooperatives. J Bank Finance 22:925-954

Athavale M, Edmister RO (2004) The pricing of sequential bank loans. Financial Rev 39:231-253

Barone G, Felici R, Pagnini M (2011) Switching costs in local credit markets. Int J Ind Organ 29:694-704

Berger AN, Udell GF (1995) Relationship lending and lines of credit in small firm finance. J Bus 68:351-381

Berger AN, Udell GF (1998) The economics of small business finance: the roles of private equity and debt markets in the financial growth cycle. J Bank Finance 22:613-673

Berger AN, Udell GF (2002) Small business credit availability and relationship lending: the importance of bank organizational structure. Econ J 112:F32-F53

Berger AN, Klapper LF, Udell GF (2001) The ability of banks to lend to informationally opaque small businesses. J Bank Finance 25:21272167

Berger AN, Miller NH, Petersen MA, Rajan RG, Stein JC (2005) Does function follow organizational form? Evidence from the lending practices of large and small banks. J Financ Econ 76:237-269

Besanko D, Thakor AV (1987) Collateral and rationing: sorting equilibria in monopolistic and competitive credit markets. Int Econ Rev 28:671-689

Bester H (1985) Screening vs. rationing in credit markets with imperfect information. Am Econ Rev 75:850-855

Bharath ST, Dahiya S, Saunders A, Srinivasan A (2011) Lending relationships and loan contract terms. Rev Financial Stud 24:1142-1203

Bonfim D, Nogueira G, Ongena S (2021) “Sorry, we're closed!” Bank branch closures, loan pricing, and information asymmetries. Rev Finance 25:1211-1259

Boot AWA (2000) Relationship banking: What do we know? J Financial Intermed 9:7-25

Boot AWA, Thakor AV (1994) Moral hazard and secured lending in an infinitely repeated credit market game. Int Econ Rev 35:899-920

Brick IE, Palia D (2007) Evidence of jointness in the terms of relationship lending. J Financial Intermed $16: 452-476$

Cassar G, Ittner CD, Cavalluzzo KS (2015) Alternative information sources and information asymmetry reduction: evidence from small business debt. J Account Econ 59:242-263

Chakraborty A, Hu CX (2006) Lending relationships in line-of-credit and nonline-of-credit loans: evidence from collateral use in small business. J Financial Intermed 15:86-107

Cole RA, Sokolyk T (2016) Who needs credit and who gets credit? Evidence from the surveys of small business finances. J Financ Stab 24:40-60

Cole RA, Goldberg LG, White LJ (2004) Cookie-cutter versus character: The micro structure of small business lending by large and small banks. J Financial Quant Anal 39:227-251

Crawford GS, Pavanini N, Schivardi F (2018) Asymmetric information and imperfect competition in lending markets. Am Econom Rev 108:1659-1701

D’Auria C, Foglia A, Reedtz PM (1999) Bank interest rates and credit relationships in Italy. J Bank Finance 23:1067-1093

Dai N, Ivanov V, Cole RA (2017) Entrepreneurial optimism, credit availability, and cost of financing: evidence from U.S. small businesses. J Corp Finan 44:289-307

Darrough MN, Stoughton NM (1986) Moral hazard and adverse selection: the question of financial structure. J Financ 41:501-513

Dass N, Massa M (2011) The impact of a strong bank-firm relationship on the borrowing firm. Rev Financial Stud 24:1204-1260

Degryse H, Ongena S (2005) Distance, lending relationships, and competition. J Finance 60:231-266

Degryse H, Van Cayseele P (2000) Relationship lending within a bank-based system: evidence from European small business data. J Financial Intermed 9:90-109 
Degryse H, Masschelein N, Mitchell J (2011) Staying, dropping, or switching: the impacts of bank mergers on small firms. Rev Financial Stud 24:1102-1140

Deng S, Wllis RH, Xu L (2014) Shareholder litigation, reputational loss and bank loan contracting. J Financial Quant Anal 49:1101-1132

Diamond DW (1989) Reputation acquisition in debt markets. J Polit Econ 97:828-862

DuGoff EH, Schuler M, Stuart EA (2014) Generalizing observational study results: applying propensity score methods to complex surveys. Health Serv Res 49:284-303

Farinha L, Santos JAC (2002) Switching from single to multiple bank lending relationships: determinants and implications. J Financial Intermed 11:124-151

Garrido MM, Kelly ASMD, Paris J, Roza K, Meier DE, Morrison RS, Aldridge MD (2014) Methods for constructing and assessing propensity scores. Health Serv Res 49:1701-1720

Gopalan R, Udell GF, Yerramilli V (2011) Why do firms form new banking relationships? J Financial Quant Anal 46:1335-1365

Hainmueller J (2012) Entropy balancing for causal effects: a multivariate reweighting method to produce balanced samples in observational studies. Polit Anal 20:25-46

Hainmueller J, Xu Y (2013) Ebalance: a Stata package for entropy balancing. J Stat Softw 54:1-18

Han L, Zhang S, Greene F (2017) Bank market concentration, relationship banking, and small business liquidity. Int Small Bus J 35:365-384

Hanley A, Crook J (2005) The higher cost of follow-up loans. Small Bus Econ 24:29-38

Hernandez-Canovas G, Martinez-Solano P (2010) Relationship lending and SME financing in the continental European bank-based system. Small Bus Econ 34:465-482

Ioannidou V, Ongena S (2010) "Time for a Change": Loan conditions and bank behavior when firms switch banks. J Financ 65:1847-1877

Jimenez G, Salas V, Saurina J (2006) Determinants of collateral. J Financ Econ 81:255-281

Levine R, Lin C, Peng Q, Xie W (2019) Communication within banking organizations and small business lending. Rev Financial Stud 33:5750-5783

Liberti JM, Petersen MA (2019) Information: hard and soft. Rev Corporate Finance Stud 8:1-41

Mkhaiber A, Werner RA (2021) The relationship between bank size and the propensity to lend to small firms: new empirical evidence from a large sample. J Int Money Finance 110:102281

Niinimäki J-P (2021) Relationship lending and switching costs under asymmetric information about bank types. J Financial Serv Res. https://doi.org/10.1007/s10693-020-00347-4

Ogane Y (2019) Effects of main bank switching on new business bankruptcy. Appl Econ 51:6286-6308

Ongena S, Smith D (2001) The duration of bank relationships. J Financ Econ 61:449-475

Ono A, Hasumi R, Hirata H (2014) Differentiated use of small business credit scoring by relationship lenders and transactional lenders: evidence from firm-bank matched data in Japan. J Bank Finance 42:371-380

Ortiz-Molina H, Penas M (2008) Lending to small businesses: the role of loan maturity in addressing information problems. Small Bus Econ 30:361-383

Ou C, Haynes GW (2006) Acquisition of additional equity capital by small firms: findings from the National Survey of Small Business Finances. Small Bus Econ 27:157-168

Peltoniemi J, Vieru M (2013) Personal guarantees, loan pricing, and lending structure in Finnish small business loans. Small Bus Manag 51:235-255

Petersen MA, Rajan RG (1994) The benefits of lending relationships: evidence from small business data. J Financ 49:3-37

Petersen MA, Rajan RG (1995) The effect of credit market competition on lending relationships. Q J Econ $110: 407-443$

Pozzolo AF (2004) The role of guarantees in bank lending. Available at SSRN: http://dx.doi.org/https://doi. org/10.2139/ssrn.498982

Rajan R (1992) Insiders and outsiders: the choice between informed and arm's-length debt. J Financ 47:1367-1400

Saparito PA, Coombs JE (2013) Bureaucratic systems' facilitating and hindering influence on social capital. Entrep Theory Pract 37:625-639

Schoar A (2012) The personal side of relationship banking. MIT Working Paper

Serrasqueiro Z, Nunes PM (2012) Is age a determinant of SMEs' financing decisions? Empirical evidence using panel data models. Entrep Theory Pract 36:627-654

Sharpe SA (1990) Asymmetric information, bank lending and implicit contracts: a stylized model of customer relationships. J Financ 45:1069-1087

SSBF (2003) Survey of small business finances by U.S. Federal Reserve 2003. https://www.federalreserve. gov/pubs/oss/oss3/ssbf03/ssbf03home.html 
Stiglitz JE, Weiss A (1981) Credit rationing in markets with imperfect information. Am Econic Rev 71:393-410

Uchida H, Udell GF, Yamori N (2012) Loan officers and relationship lending to SMEs. J Financial Intermed 21:97-122

Von Thadden E (2004) Asymmetric information, bank lending and implicit contracts: the winner's curse. Financ Res Lett 1:11-23

Wilde JH (2017) The deterrent effect of employee whistleblowing on firms' financial misreporting and tax aggressiveness. Account Rev 92:247-280

Wu Z, Chua J (2012) Second-order gender effects: the case of U.S. small business borrowing cost. Entrep Theory Pract 36:443-463

Publisher's Note Springer Nature remains neutral with regard to jurisdictional claims in published maps and institutional affiliations. 